\title{
“I Speak My Language My Way!"-Young People’s Kunwok
}

\author{
Alexandra Marley ${ }^{1,2}$ (D) \\ 1 Centre for National Biodiversity Research (CANBR) and Australian National Herbarium (ANH), \\ National Collections and Marine Infrastucture (NCMI), CSIRO, Black Mountain, ACT 2601, Australia; \\ alexandra.marley@csiro.au \\ 2 CoEDL, Australian National University, Acton, ACT 261, Australia
}

Citation: Marley, Alexandra. 2021.

"I Speak My Language My

Way!"-Young People's Kunwok.

Languages 6: 88. https://doi.org/

10.3390/languages6020088

Academic Editors: Carmel

O'Shannessy, Elisabeth Mayer, Jane

Simpson, Juana M. Liceras and

Raquel Fernández Fuertes

Received: 29 January 2021

Accepted: 23 April 2021

Published: 14 May 2021

Publisher's Note: MDPI stays neutral with regard to jurisdictional claims in published maps and institutional affiliations.

\begin{abstract}
Bininj Kunwok is a Gunwinyguan language (a non-Pama-Nyungan) spoken in west Arnhem Land and Kakadu National Park, NT, Australia. With around 2500 speakers and children learning it as a first language, Kunwok is one of the strongest Indigenous languages in Australia. Despite its small speech community, it exhibits considerable variation, much of which has been the subject of recent research. One of the primary findings from this study into variation in Kunwok is the rich interspeaker diversity, particularly between different generations of Kunwok speakers. Comparing the speech of young adults and children with that of their elders through a multigenerational corpus has revealed a language change in progress (demonstrated both in real time and apparent time). This paper will discuss three of the key differentiating features of young people's Kunwok: word-initial engma production, pronominal forms and paradigms and loanwords. We will also examine community members' perspectives on young people's Kunwok on the basis that they provide insight into the ideological frameworks that support the linguistic variation and change documented in the community. In conclusion, the paper will summarise the findings, outlining the main features of young people's Kunwok, and then reflect on the trajectory of Kunwok and the contributions of this study to our understanding of language change in the Australian Aboriginal context.
\end{abstract}

Keywords: language variation and change; language contact; Gunwinyguan; clusivity; paradigms; borrowing; loanwords; linguistic ideologies

\section{Introduction}

Bininj Kunwok (or simply Kunwok) is a Gunwinyguan language spoken in western Arnhem Land and Kakadu National Park. With an estimated 2500 speakers, it is one of the few Australian languages to be actually gaining speakers (Evans 2003), as many speakers of the neighbouring languages have switched to Kunwok (e.g., Giimbiyu (Mengerrdji, Erre, Urningangk), Gaagudju, Amurdak, Ngaduk, Gonbudj, Ngombur, Umbugarla, Jawoyn, Dalabon, Rembarrnga and Kunbarlang (see Figure 1). The traditional country of Kunwok speakers is around the Arnhem Land plateau, from east of Cooper Creek stretching towards Cadell Creek, southwest along the Mann River towards Katherine, then north-north-east to the East Alligator River.

The largest concentration of Kunwok speakers is in Kunbarlanja, a settlement with around 800 speakers. The township is on land originally belonging to Mengerrdji speakers (a variety of Giimbiyu), but with the establishment of a cattle station and later a mission, many of the neighbouring peoples have come to stay in the area. The most central variety of Kunwok (geographically), usually referred to as Kunwinjku, was a lingua franca in the area, and the mission chose this language to work with and the other languages began to fade from use. The regional varieties of Kunwok are Kundjeyhmi, Kundedjnjenghmi, Kunwinjku, Kuninjku, Kune and Manyallaluk Mayali and are still spoken to varying degrees. Speakers will generally refer to one of these dialectal names when describing their language, and the term 'Bininj Kunwok', meaning the Bininj people's language (kunwok), is generally only used by linguists to describe the dialects as a single group. The 
southern varieties of Kundjeyhmi, Manyalluluk Mayali and Kundedjnjenghmi are referred to collectively by Evans (2003) in his pan-dialectal grammar as Mayali and are now rarely spoken, with speakers either having levelled dialectal features or shifted to English or Kriol (an English-based creole). By contrast, the eastern varieties of Kuninjku and Kune spoken in Maningrida and the family outstations it supports (those east of the Mann river) have retained their distinct features, which include an extra vowel (Kune only), morphological distinctions (e.g., the partitive suffix -no) as well as numerous lexical variations, particularly in flora and fauna. Dialectal levelling and the effects of contact with English are most prominent in the speech of the younger Bininj, and this paper focuses on the most salient of these manifestations of change.

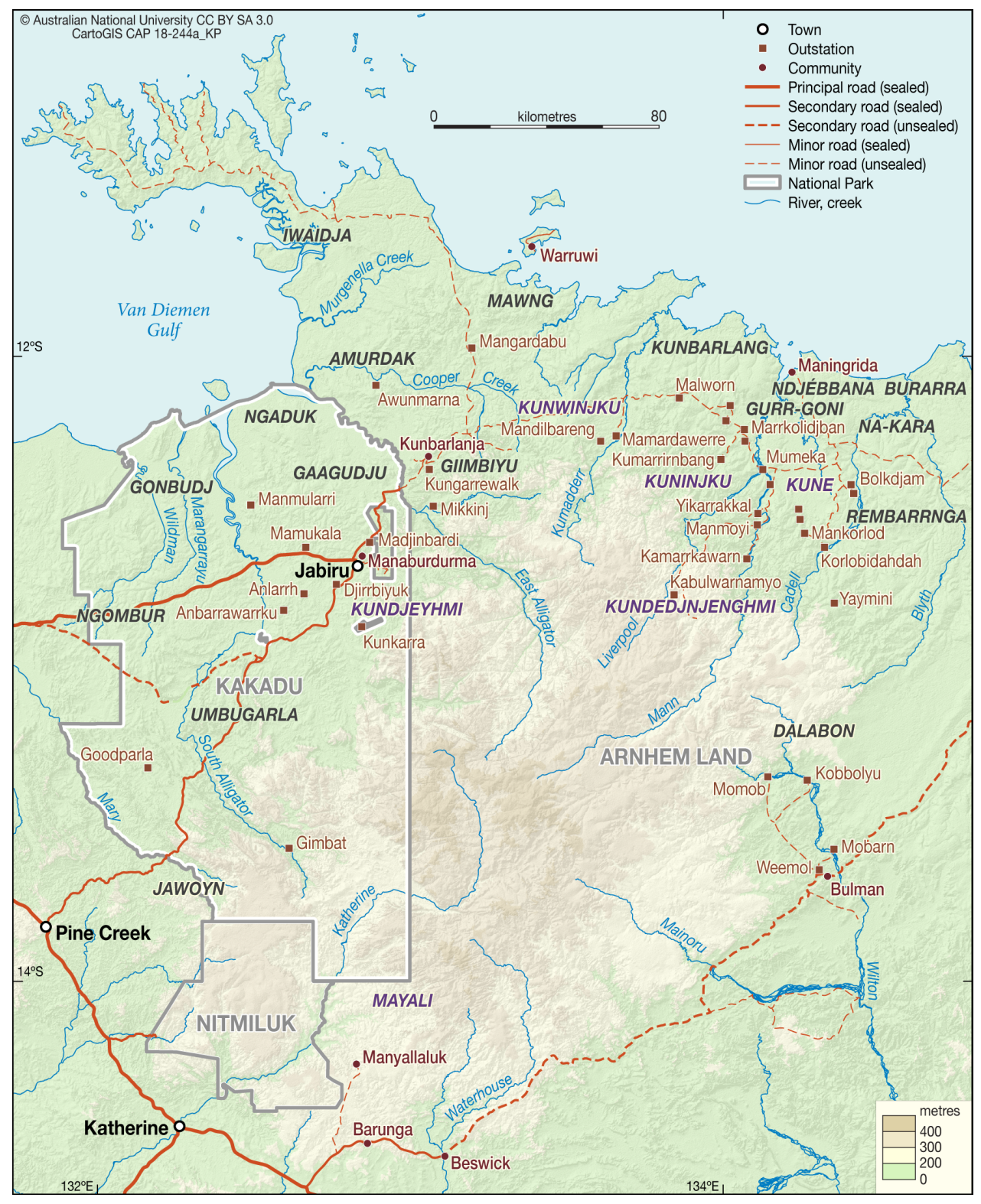

Figure 1. Map of Bininj Kunwok speaking region. Reprinted from Marley (2020, p. 9).

To frame the analysis of these changes, we begin with a review of the primary relevant theories of language variation and change, particularly with respect to the Australian context (Section 2). In Section 3, discussion will focus on key areas of change in young people's Kunwok, the first of which is a sound change in the form of initial engma deletion (Section 3.1). The second area of change is in the pronominal prefixes, both in the forms (Section 3.2.1) and in paradigm shape (Section 3.2.2). Thirdly, we consider lexical change, 
specifically looking at the rate and nature of English and Kriol loanwords (Section 3.3). Following this, we examine the community perceptions of language change (Section 4) and then compare these results to similar reports of language change in other Australian Aboriginal communities. To conclude, we reflect on the future shape of Kunwok.

\section{Identifying Variation and Change}

In the past two decades, there has been a shift in thinking around language contact and language variation and change. With a heavy focus on bilingualism, creolisation and pidginisation, language contact studies have generally adopted the default historical stance that contact inevitably leads to structural convergence and simplification, a process which involves a regularisation of morphology and a reduction in marked features (Meakins et al. 2019) (see also Miestamo et al.'s (2008) edited volume on complexity reduction as a result of contact). However, an increasing number of studies have demonstrated that contact does not necessarily promote convergence or simplification (Poplack 2018; Poplack and Levey 2010; Torres Cacoullos and Travis 2015, 2018). Furthermore, in some scenarios, contact actually leads to divergence and even complexification, whereby paradigmatic irregularity and redundancy and analytical opacity from allomorphy and fusional structures are increased (Braunmüller et al. 2014; Evans 2019). These latter findings challenge not only historical assumptions but sociolinguistic impressions of contact. For instance, Trudgill's (2009, 2011) sociolinguistic typology hypothesis positively correlates complexification with small, tight-knit communities with dense social networks and low contact levels. While Trudgill's proposal is not outright refuted by evidence of divergence-despite-contact, it demonstrates that there is still considerable work to be done in uncovering the motivations that determine the direction of language change in contact situations.

Studies of language change, variation and contact in Australia have made significant contributions to expanding this avenue of thought. There is a considerable amount of literature on modern incarnations of Australian languages, particularly with respect to contact effects (Dickson 2015; Langlois 2004; Lee 1987; Mansfield 2014; McConvell and Meakins 2005; Meakins and O'Shannessy 2016; O'Shannessy 2005; Sandefur 1986; Schmidt 1983), and many of these document the maintenance of complexity or complexification alongside simplification processes. Gurindji Kriol and Light Warlpiri, for instance, are two Australian mixed languages derived from the Ngumpin-Yapa languages Gurindji and Warlpiri (respectively) and English/Kriol. In both Gurindji Kriol and Light Warlpiri, a reductive effect on morphological complexity anticipated by language contact studies is not forthcoming in the data (Meakins and O'Shannessy 2012). Rather, the mixed codes are a fusion of two languages, which both contribute equally to the formation of the new variety. This is unlike creoles and pidgins, which usually have a clear dominant superstrate language (often a colonial language such as English) and one or more substrate languages. Mixed languages also differ in their socio-historical origins: while creoles and pidgins come about as a result of communicative necessity between two groups who do not speak each other's language, it is postulated that mixed languages tend to arise in bilingual communities that are seeking a new mode of self expression (Meakins 2012).

In addition to variation as a result of contact with English (through loanwords, as discussed in Section 3.3), Kunwok also has evidence of dialect-contact-motivated variation (such as word-initial engma deletion, as discussed in Section 3.1) and variation that follows well-worn cross-linguistic evolutionary paths. For example, the initial-consonant deletion found in Kunwok is a recurrent process in the region (Blevins 2001; Dixon 2002; Fletcher and Butcher 2014; Hale 1964), and the variable is attested even in the oldest speakers in the Bininj Kunwok Corpus (Section 3.1). Likewise, the neutralisation of number in the inclusive non-minimal and regularisation of the second person prefix forms (Section 3.2) is well-documented cross-linguistically, as marked (i.e., rare and/or irregular) forms such as these are known and predictable sites of weakness in pronominal paradigms (Corbett 2004; Cysouw 2003). In contrast, English and Kriol loanwords are obvious consequences of contact, but the variation in strategies used to import loan verbs hints at potential 
syntactic changes which may emerge in the future. In short, Kunwok exhibits a range of variation at different linguistic levels that is attributable to different processes. Given that the community is bilingual in Kunwok and English, there is conceivably potential for the development of a mixed language. This line of inquiry is returned to in Section 5.

\section{Features of Young People's Kunwok}

Identifying variation and change in Kunwok began with the development of the Bininj Kunwok Corpus (BKC ${ }^{1}$ ), which currently contains 48,718 words (27.5 h) of naturalistic and elicited speech data sourced from archival collections and from the author's fieldwork from 2016-2019. This means the BKC spans a recording range of around 60 years, with the earliest included texts from (Berndt and Berndt 1951) and (Hale 1959) ${ }^{2}$. The transcription and analysis of the speech data of 98 Kunwok speakers from across the region-45 women and 63 men, aged from 6 to around 86, and spanning a date of birth range of over a century (1907-2010) - made it possible to explore not only synchronic variation but also diachronic variation. The statistical analysis of the corpus data is complemented with sociolinguistic and ethnographic observations made during field-trips. Including this qualitative data was vital to providing a holistic approach and gaining insight into the socio-psychogical and cultural motivations behind the language use patterns of young Bininj, more of which is discussed in Section 4.

The analysis of the BKC revealed an astounding amount of inter and intra-speaker variation (Marley 2020) considering the size of the community and the dataset. Here, the primary features associated with the younger third of the corpus are collated and examined. The three generational groups were arrived at by dividing the 103 year birth-date span into three groups of 34 year periods and are as follows: Generation (Gen) 1: 1907-1944, Gen 2: 1945-1976 and Gen 3: 1977-2010. ${ }^{3}$ Grouping speakers in this way permitted the statistical analysis of linguistic variables with insufficient token numbers per person. In the case of the sound change, there were enough tokens per speaker to plot individual speaker data over time (See Figure 2).

\subsection{Word-Initial Engma Deletion}

The first area of change examined here is phonological. Phonologically, Kunwok has some typical features of Australian languages: it has a $\mathrm{CV}(\mathrm{C})(\mathrm{C})$ syllable structure (Dixon 1980), a "long flat" consonant series lacking voicing contrast and manner-of-articulation contrast in the obstruents (Butcher 2006) and makes regular use of the velar nasal (/y/) in the word-initial position (Donohue et al. 2013). The weakening or deletion of initial consonants is a well-known phenomenon in Australian languages; however, studies have tended to take a historical perspective (e.g., Alpher 1976; Hale 1964; Dixon 1980, 2002; Blevins 2001; Fletcher and Butcher 2014; Hercus 1979), focusing on diachronic changes and phonetic trends, rather than a sociolinguistic synchronic view (as adopted by Amery 1985; Langlois 2004; Mansfield 2015). Languages neighbouring Kunwok that have some sort of initial consonant lenition documented include Giimbiyu, Gaagudju, Amurdak, Iwaidja, Mawng, Kunbarlang, Burarra and Ngalakgan (Blevins 2001). Engma is considered to be particularly susceptible to deletion as it has weak perceptual cues, along with other velars, nasals, labials and glides (Fletcher and Butcher 2014, p. 112).

In Kunwok, initial engma deletion is restricted to closed-class morphemes: noun class and gender prefixes, pronominal prefixes, free pronouns and kin terms ${ }^{4}$ (Marley 2020, forthcoming). Examples (1) and (2) demonstrate how this variable manifests. Note that free pronouns (e.g., ngaye and ngayed) and pronominal prefixes (e.g., nga-) may drop the initial velar nasal in example (2) but that prefixless (or zero-prefixed) noun and verb roots such as "Echidna" (ngarrbek) and "be called/named" ngeyyo do not permit the initial nasal to be dropped: 
(1) Sentence with initial engma:

Ngarrbek ø-ngeyyoy ... ø-yimeng 'ngaye nga-re ku-wardde'

Echidna 3m-be.called.PI 3m-say.PP 1sg.DIR 1m-go.NP LOC-rock

"Her name was Echidna ... and she said 'I'm going to the stone country."

BKC_Carroll_D6

(2) Sentence with initial engmas deleted:

_A-neke yi-yimerranj, _ayed_a-yimarrang?_Al-wanjdjuk_a-yimarra! VEG.DEM 2m-become.PP what 1m-become.NP FE-emu 1m-become.IMP

“That's what you turned into, [but] what will I turn into? I'll become an emu!"

BKC_Evans1991_Alwanjuk_emu

Initial engma deletion is also regionally distributed, with speakers from the eastern region of the dialect chain rarely exhibiting the deleted variant while speakers from the west and south have traditionally always dropped it (Evans 2003). Bininj from the central region (Kunwinjku speakers) vary in their behaviour, with some speakers never dropping engma, others consistently dropping engma and many showing considerable internal variation (example 3).

(3) Ngarrbek ø-yimeng 'Aye wanjh nga-re ku-wardde nani'. Wanjh Echidna 3m-say.PP 1sg.DIR CONJ 1m-go.NP LOC-rock MA.DEM CONJ almangayiø-yimeng 'Mak ngaye nga-re kabbal nga-yo'. FE.turtle 3m-say.PP INTERJ 1sg.DIR 1m-go.NP plains 1m-lie.NP

“Echidna said 'I'm going to the stone country then' and turtle said 'Well I'm going to live on the floodplains'."

BKC_Marley_Conrad_echidnaTortoise01

Diachronic analysis of the word-initial engma variable in the BKC indicated that engma deletion is becoming more common over time, particularly in speakers from the central region. The chart in Figure 2 plots individual speaker data (where $n \geqslant 30$ tokens per speaker) by their birth year and by region. Trendlines ${ }^{5}$ for each of the three regional groups indicate that Eastern Kunwok speakers (Kune/Kuninjku) have maintained a low rate of deletion, while there is likely to be a sound change in progress for Kunwinjku speakers as they have had a clear and significant $(p=0.00003)$ increase in initial engma deletion over time. Note that the Mayali data are somewhat skewed as the youngest speaker in this sample was born in 1975, and so the Kunwinjku speakers in this dataset are the only ones whose Kunwok is changing. 
Speakers by region over time $n \geq 30$

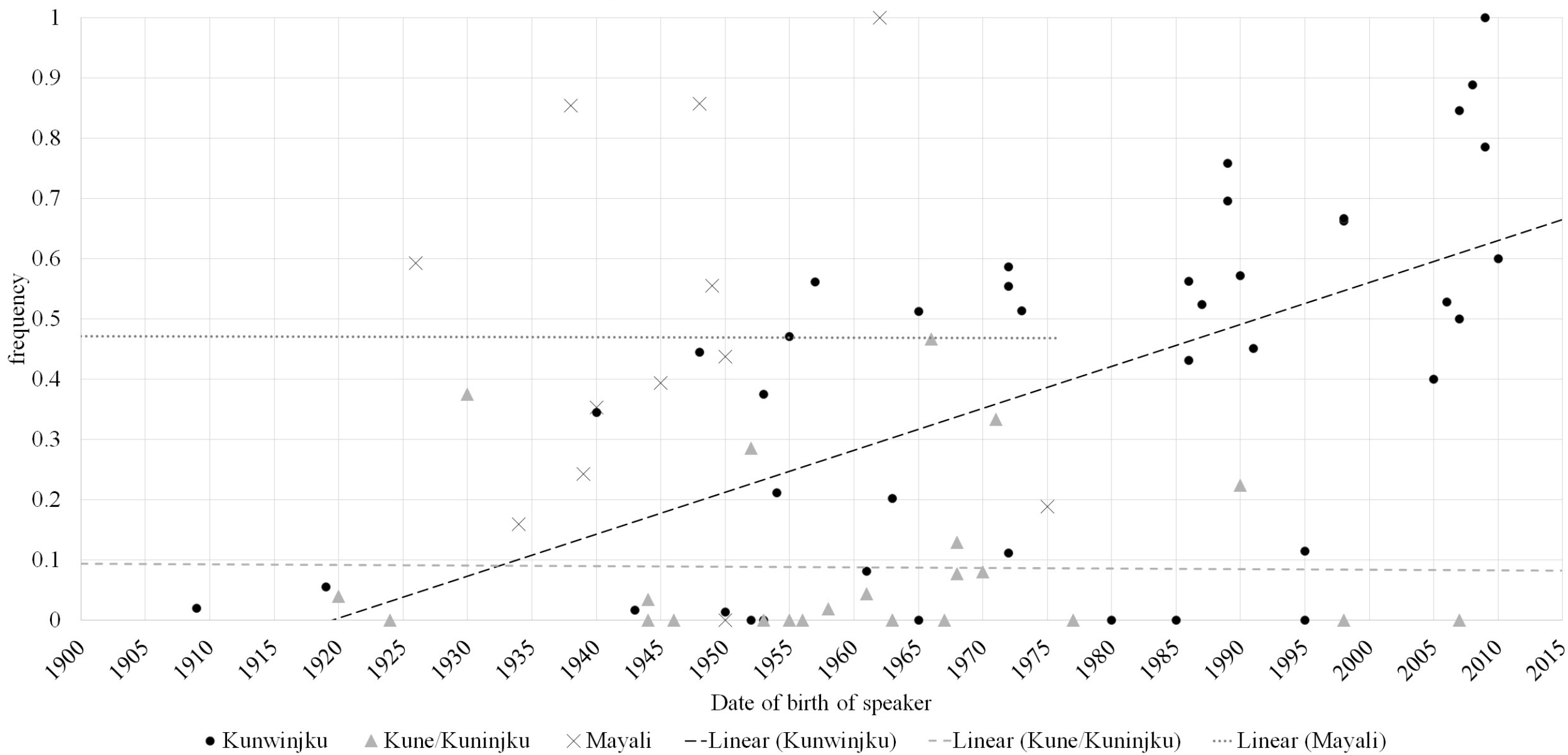

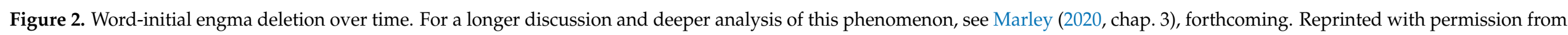
Marley (2020) 
An age-grading hypothesis for the observable change is unlikely as the recordings span a 60 year period (1959-2019) with several of the older speakers in the BKC recorded when they were young adults. As for Bininj from the east, while there are some outliers, current data suggest that they have not (yet) adopted the variable, possibly helped by the fact that communities in that region tend to socially align themselves with their Rembarrnga and Dalabon-speaking kin, and neither language has been documented to delete the initial engma.

\subsection{Pronominal Prefixes in Kunwok}

Kunwok has both bound and free pronominal forms, but this paper focuses only on the obligatory bound forms (Evans 2003). As with most non-Pama-Nyungan languages, Kunwok is a prefixing language with a rich system of pronominal prefixes that affix to verb stems (example (4)) as well as nouns, adverbs, adjectives and numerals (example (5)):

(4) Prefix on verb stem:

$$
\begin{aligned}
& \text { Ngurri-wam } \\
& \text { 2a-go.PP }
\end{aligned}
$$

"You mob went"

(5) Prefix on numeral and nominal predicate:

$$
\begin{aligned}
& \text { Bu ngarri-danjbik ngarri-wurdurd-ni } \\
& \text { CONJ 1a-three 1a-child-PI }
\end{aligned}
$$

"When we three were children"

As Kunwok is a polysynthetic language, its verbs can take multiple arguments. A result of this is a set of prononimal prefixes that code both subject and object in a single form, many of which have a semi-regular structure. The convention used for glossing composite transitive pronominal forms is "Subject > Object"; e.g., ngaben- $1 \mathrm{~m}>3 \mathrm{pl}=1 \mathrm{~m}$. SUB acting on 3 pl.OBJ.

$$
\begin{array}{llll}
\text { ngabenbene- } & 1 \mathrm{~m}>3 \mathrm{du} & \begin{array}{l}
\text { ngaben- } \\
\text { ngarrbenbene- }
\end{array} & 1 \mathrm{~m}>3 \mathrm{~m}>3 \mathrm{du} \\
\text { ngarrben }- & 12 \mathrm{~m}>3 \mathrm{pl} \\
\text { yibenbene- } & 2 \mathrm{~m}>3 \mathrm{du} & \text { yiben- } & 2 \mathrm{~m}>3 \mathrm{pl} \\
\text { benbene- } & 3 \mathrm{~m}>3 \mathrm{du} & \text { ben- } & 3 \mathrm{~m}>3 \mathrm{pl}
\end{array}
$$

This compounding structure, however, is not consistent throughout the whole paradigm, with some combinations syncretising across number, person or clusivity boundaries.

$$
\begin{array}{ll}
\text { bindi- } & 3 \mathrm{ua} / 3 \mathrm{a}>3 \mathrm{du} / 3 \mathrm{pl} \\
\text { ngundi- } & 3 \mathrm{a}>2 / 1 \mathrm{a}>2
\end{array}
$$

To complicate things further, there are two different formulating patterns for the subject and object. Subjects use a "minimal I unit-augmented I augmented" system (McKay 1975) while objects adhere to the more common singular I dual I plural number marking. The minimal I unit-augmented l augmented ( $\mathrm{min} / \mathrm{ua} / \mathrm{aug}$ ) is a way of categorising pronouns according to relative number (Table 1) instead of absolute number (Table 2). It is applied to pronominal systems that mark clusivity and have a singular I dual I plural number system. 
Table 1. Kunwinjku intransitive pronominal prefixes schematised by relative number, resulting in a much neater paradigm arrangement.

\begin{tabular}{|c|cccc|}
\hline \multicolumn{5}{|c|}{ Intransitive pronominal prefixes } \\
\hline & singular & dual & trial & plural \\
\hline First excl. (1) & $n g a-$ & ngane- & - & ngarri- \\
\hline First incl. (12) & - & $n g a r r-$ & kane- & karri- \\
\hline Second (2) & $y i-$ & ngune- & - & ngurri- \\
\hline Third (3) & $($ ka)ø- & (ka)bene- & - & (ka)birri- \\
\hline
\end{tabular}

Table 2. Kunwinjku intransitive pronominal prefixes schematised by absolute number. Note the gaps in the matrix cells as a result of undefined person number distinctions.

\begin{tabular}{|c|ccc|}
\hline \multicolumn{4}{|c|}{ Intransitive pronominal prefixes } \\
\hline & minimal (m) & unit augmented (ua) & augmented (a) \\
\hline First excl. (1) & $n g a-$ & $n g a n e-$ & $n g a r r i-$ \\
\hline First incl. (12) & $n g a r r-$ & kane- & karri- \\
\hline Second (2) & $y i-$ & $n g u n e-$ & $n g u r r i-$ \\
\hline Third (3) & $(k a) ø-$ & $(k a) b e n e-$ & $(k a)$ birri- \\
\hline
\end{tabular}

Evidence that a min I ua I aug arrangement is the most logical schematisation can be seen in the morphological structures of the pronouns; note that all augmented forms end in -rri and all unit-augmented forms end in -ne, suggesting that this arrangement is inherent to the language and not only the wishful projection of order onto the system by linguists.

The transitive pronominal paradigm is a somewhat larger and more convoluted matrix. Table 3 illustrates how the subjects can be placed on the $y$-axis and objects on the x-axis to create a schema of an attested pronominal prefix paradigm. In the instances where the subject and object are the same (i.e., the blacked-out cells), a reflexive or reciprocal suffix is used with an intransitive prefix form (e.g., ngane-na-rr-en [1ua-see-RR-NP], "We were looking at each other").

This matrix presents the most frequent realisations of the prefixes in the existing grammatical descriptions of Kunwok (Carroll 1976; Evans 2003; Hale 1959; Oates 1964) but a survey of individual speaker paradigms revealed considerable variation. By comparing the attested pronominal forms of speakers in the BKC, two patterns emerged that correlated with speaker age. The first was the regularisation of second person prefixes, such that the non-singular second person forms (beginning with $n g u-$ ) are brought into line with the singular form yi-, resulting in ngune- (2ua) and ngurri- (2a), respectively, being produced as yine- and yirri- (Section 3.2.1). The second recurring deviation in the above paradigm is in the first-person subject, where there is evidence of number neutralisation and obsolescence of the 12ua form kane- (Section 3.2.2). 
Table 3. Canonical Kunwinjku pronominal prefixes. Adapted with permission from (Evans 2003, p. 403).

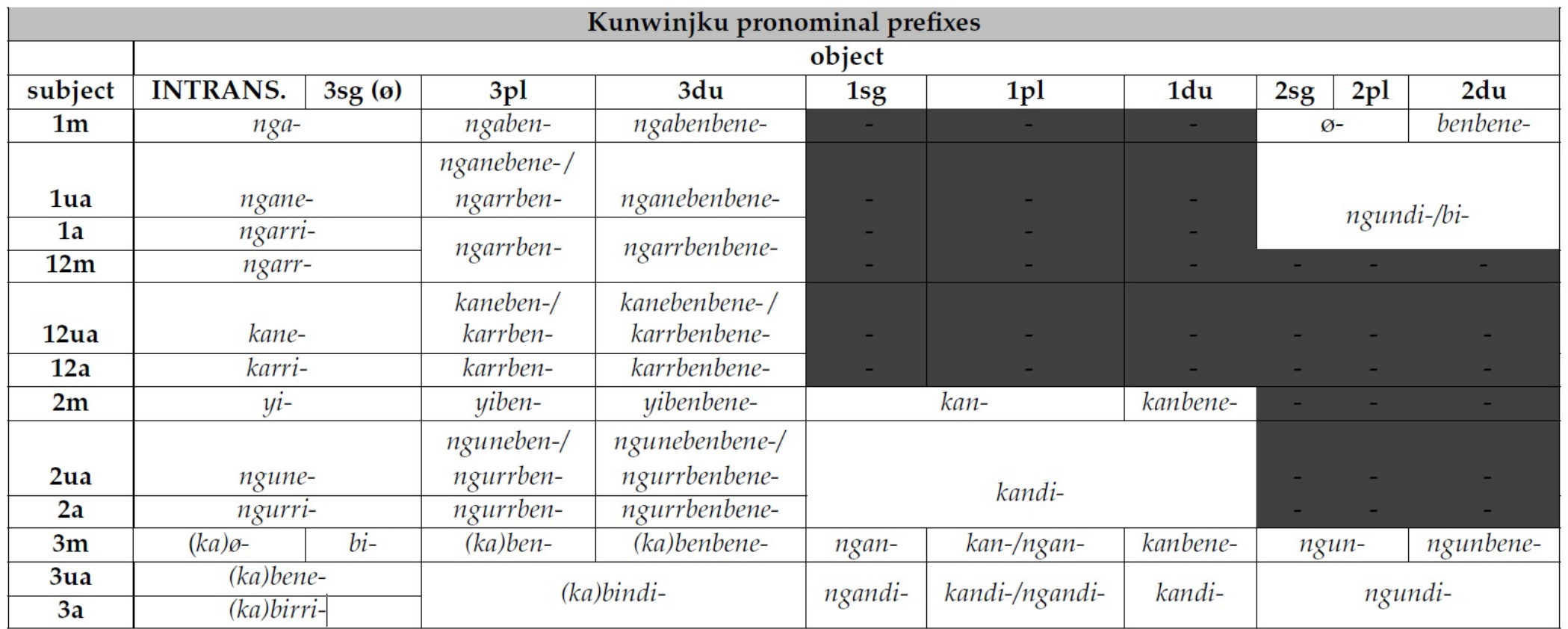




\subsubsection{Regularisation of Second Person Prefixes}

The second feature of young people's Kunwok is a regularisation pattern observed in the second person non-minimal forms (i.e., ua and aug). The regularised forms were first noticed in children's speech during fieldwork in 2016; however, this pattern has since been recorded in the speech of adults aged up to 45 years (examples 6 and 7 ).

(6) Baleh ngudda yine-ma.ng where 2.DIR 2ua $>3$ sg-get.PP

"Where did you get it?"

Janet, 20 years

BKC_Singer_RS1-371 DM2 landmark interview ext lg_JM_RS

(7) Like yi-bengkan udda yirri-wam the other day kakkak-dorreng Beatrice like 2sg-remember.NP 2.DIR 2a-go.PP the other day MM-COM Beatrice "Like, do you remember, you went with kakkak Beatrice the other day"

Chantelle, 31 years BKC_Marley_Chantelle_kin_Convo

The resulting regularised paradigm is shown here (Table 4):

Table 4. Regularisation in intransitive pronominal prefixes exhibited in children's speech in Mamardawerre (in bold). For reference, standard forms are in brackets.

\begin{tabular}{|c|ccc|}
\hline \multicolumn{4}{|c|}{ Intransitive pronominal prefixes } \\
\hline & minimal (m) & unit augmented (ua) & augmented (a) \\
\hline $\mathbf{1}$ & $n g a-$ & $n g a n e-$ & ngarri- \\
\hline $\mathbf{1 2}$ & $n g a r r-$ & kane- & karri- \\
\hline $\mathbf{2}$ & yi- & yine- $($ ngune- $)$ & yirri- $($ ngurri-) \\
\hline 3 & $($ ka)ø- & (ka)bene- & $($ ka)birri- \\
\hline
\end{tabular}

Further investigation revealed that speakers who employed this regularised second person prefix also extended this pattern deeper into the paradigm to regularise any pronominal form beginning with $n g u$ - (examples (8)-(10)).

(8) Wurdurd ngaye ngal-kodjok and al-kangila yindi-bekkan children 1sg.DIR II-skin.name and II-skin.name 1a >2pl-listen.NP

"Children, Ngal-kodjok, Ngal-kangila and I are listening to you"

Alexandria, 19 years

BKC_Marley_Alexandria_prns

(9) Yawurrinj boken yinebenbene-na.yinj al-kodjokodjok young.man two 2ua $>3 \mathrm{du}$-see.IRR II-REDUP.skin.name

"Guys, did you two see Al-kodjokodjok?"

Lorina, 19 years

BKC_Marley_Lorina_prns 
(10) Mah yin-bengkan ka-yime 'beautiful' INTERJ 3m > 2sg-know.NP 3m.NP-say.NP beautiful

"So she'll teach you how to say 'beautiful"

Chantelle, 31 years

BKC_Marley_Chantelle_kin_Convo

All pronominal prefixes that begin with $n g u$ - refer to the second person in some way, either as a subject or object, and so the regularisation pattern is occurring in the whole second person prefix series and not only the intransitives (Tables 5 and 6):

Table 5. Regularised second person subject paradigm.

\begin{tabular}{|c|c|c|c|c|}
\hline & \multicolumn{3}{|c|}{ OBJECT } \\
\hline & & $3 s g$ & $3 d u$ & $3 \mathrm{pl}$ \\
\hline \multirow{3}{*}{ 崩 } & $2 \mathrm{~m}$ & $y i-$ & yibenbene- & yiben- \\
\hline & 2 ua & $\begin{array}{c}\text { yine- } \\
\text { (ngune-) }\end{array}$ & $\begin{array}{c}\text { yinebenbene- } \\
\text { (ngunebenbene-) }\end{array}$ & $\begin{array}{c}\text { yineben- } \\
\text { (nguneben-) }\end{array}$ \\
\hline & $2 a$ & $\begin{array}{c}\text { yirri- } \\
\text { (ngurri-) }\end{array}$ & $\begin{array}{l}\text { yirr(i)benbene- } \\
\text { (ngurrbenbene-) }\end{array}$ & $\begin{array}{l}\text { yirr(i)ben- } \\
\text { (ngurrben-) }\end{array}$ \\
\hline
\end{tabular}

Table 6. Regularised second person object paradigm.

\begin{tabular}{|c|c|c|c|}
\hline & \multicolumn{2}{|c|}{ ОВЈЕСТ } \\
\hline & & $2 \mathrm{sg}$ & $2 d u$ \\
\hline \multirow{6}{*}{ 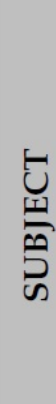 } & $1 \mathrm{~m}$ & $\varnothing-$ & benbene- \\
\hline & 1ua & \multirow{2}{*}{\multicolumn{2}{|c|}{$\begin{array}{c}\text { yindi- } \\
\text { (ngundi-) }\end{array}$}} \\
\hline & $1 \mathrm{a}$ & & \\
\hline & $3 m$ & $\begin{array}{c}\text { yin- } \\
(\text { ngun-) }\end{array}$ & $\begin{array}{c}\text { yinbene- } \\
\text { (ngunbene-) }\end{array}$ \\
\hline & 3 ua & \multirow{2}{*}{\multicolumn{2}{|c|}{$\begin{array}{c}\text { yindi- } \\
\text { (ngundi-) }\end{array}$}} \\
\hline & $3 \mathrm{pl}$ & & \\
\hline
\end{tabular}

Not all speakers who produced yine- and yirri-consistently transferred this pattern across to the more complex forms in the paradigm, and some speakers exhibited internal variation using both the canonical (ngurri-) and the regularised (yirri-) forms (example (11)):

(11) Mah yirri-ray kurih ngurri-dirri well 2a-go.IMP there 2a-play.NP

"Well go over there and play"

Chantelle, 31 years

BKC_Marley_Chantelle_kin_Convo

Only 11 speakers in the BKC were recorded with a regularised form, so this phenomenon is still emergent. Figure 3 plots the second person non-singular prefix forms in the BKC over three generations: Gen 1: 1907-1944, Gen 2: 1945-1976 and Gen 3: 1977-2010. The total number of speakers represented here is 58 , as 40 speakers had no tokens of the 
non-singular/minimal second person (as either subject or object) in their dataset and so were omitted from this analysis. This chart shows that the majority of the documented regularisation in the BKC is found in Generation 3's data, while no one in Generation 1 was found to regularise.

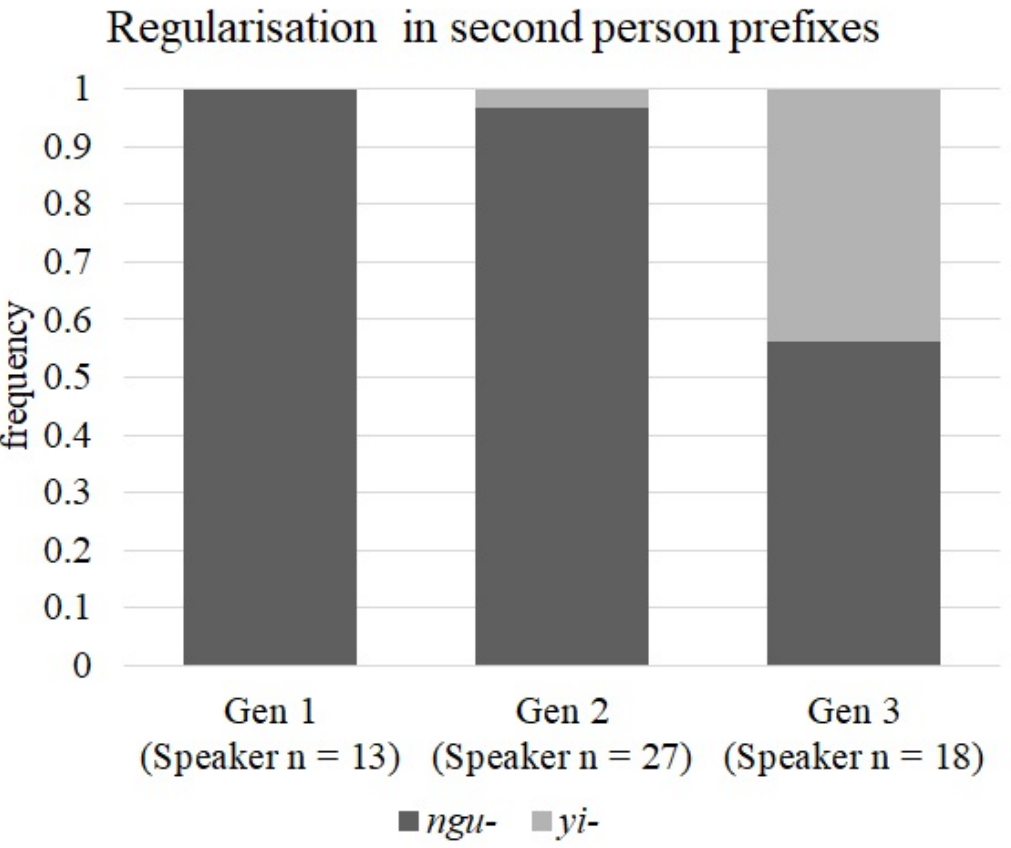

Figure 3. Second person prefix regularisation rates of three generational groups in corpus data.

Overall, 12 speakers were recorded regularising: 11 from Gen 3 and 1 from Gen 2 . This single Gen 2 speaker stands out, not only because he is the only representative of his generation here, but also because he is one of only two men recorded regularising. It is tempting to posit that this is a female-led change; however, this is an artefact of the skewed nature of the dataset: of the 39 members of Gen 3 in the BKC, only 7 are male. Future research specifically focusing on the speech of young Bininj will no doubt provide greater detail as to the leaders of change in this group.

Finally, the regularisation pattern does not extend to the free pronouns. Note that in example (6), the speaker uses the second person direct pronoun ngudda, which remains unaffected by the changes occurring in the prefixes, as do the other second person free pronouns (Table 7). This regularisation means that the link between bound and free forms is becoming much more opaque, with a dual root system emerging where free pronouns begin with $n g u$ - (with the exception of the emphatic singular yingan) but bound pronouns use the $y i$ - root.

Table 7. Second person free pronouns.

\begin{tabular}{|c|ccc|}
\hline \multicolumn{4}{|c|}{ Intransitive pronominal prefixes } \\
\hline & minimal (m) & unit augmented (ua) & augmented (a) \\
\hline $\mathbf{1}$ & $n g a-$ & $n g a n e-$ & $n g a r r i-$ \\
\hline $\mathbf{1 2}$ & $n g a r r-$ & kane- & karri- \\
\hline $\mathbf{2}$ & $y i-$ & yine- $(n g u n e-)$ & yirri- $($ ngurri-) \\
\hline 3 & $(\mathrm{ka}) \emptyset-$ & $(\mathrm{ka})$ bene- & $(\mathrm{ka})$ birri- \\
\hline
\end{tabular}


This deepening divide between bound and free forms is a predicted step in the evolution of pronouns. Australian languages are said to cycle between bound and free pronouns, with one series feeding the other (Dixon 2002; Harvey 2003), with Dixon proposing the following evolutionary stages (p. 354):

Stage I Bound pronouns are identical to free forms or are a transparent reduction from them;

Stage II Bound pronouns are substantially (or totally) different from free pronouns; Stage III The old free pronouns have been lost and new ones formed, involving the addition of bound pronominal affixes or clitics to an invariable root.

Several of the Gunwinyguan and neighbouring non-Pama-Nyungan languages ${ }^{6}$ have been identified as being at Stage II of this cycle, including Kunwok (Dixon 2002, p. 357), but the ongoing decrease in transparency between free and bound second person pronouns in Kunwok potentially indicates a transition to a more advanced step within Stage II.

\subsubsection{First Person Clusivity and Number Neutralisation}

Regularisation is not the only way that young Bininj are varying Kunwok pronominal prefixes. There is considerable evidence that number marking in first person inclusive prefixes is also undergoing a change. The locus of instability in a min I ua I aug system is in the first person non-singulars, where there is effectively a five-way distinction between non-singular first person forms:

\begin{tabular}{|c|c|c|c|}
\hline & minimal & unit augmented & augmented \\
\hline 1 & $n g a-$ & ngane- & ngarri- \\
\hline 12 & ngarr- & kane- & karri- \\
\hline
\end{tabular}

A survey of the first person pronominals in the BKC indicated that number distinction and clusivity opposition are potential sites of change. The prefix typically denoting $12 \mathrm{ua}$ kane- is particularly sensitive to neutralisation, most likely because it is so uncommon. Of 2203 tokens of first person plural prefixes, only 17 tokens were kane-, and all of these were produced by speakers born before 1973 (Table 8).

Table 8. Count of first person plural prefixes across three generations. Gen 1: 1907-1944, Gen 2: 1945-1976, Gen 3: 1977-2010.

\begin{tabular}{lcccc}
\hline & \multicolumn{2}{c}{ Token Count } \\
\hline Prefix & Gen 1 & Gen 2 & Gen 3 & Total \\
\hline ngarri- & 325 & 726 & 252 & 1307 \\
karri- & 217 & 305 & 86 & 606 \\
ngane- & 75 & 69 & 7 & 150 \\
ngarr- & 56 & 66 & 2 & 125 \\
kane- & 9 & 8 & 0 & 17 \\
\hline total & 682 & 1174 & 347 & 2203 \\
\hline
\end{tabular}

The data suggest that kane- is obsolete for young Bininj-a trend that is further supported by the fact that the corresponding 12 ua free oblique pronoun karrewoneng is not attested at all in the BKC. The absence of both 12 ua pronominals points towards a general decline in the salience of the unit-augmented inclusive context and raises the question of which direction the unit-augmented inclusive (12ua) is neutralising in; i.e., with the minimal or with the augmented? From my own observations, it is the augmented which is absorbing the 12ua meaning - a not unexpected direction since three would normally be 
treated as augmented in other persons. The corpus only catches four tokens of karri- with the inclusive unit-augmented (12ua) meaning, but I often took the opportunity when I was with only two consultants (i.e., only three of us) to ask how I might say "let's go", with the response most often being karri-re. Likewise, when I was with three Bininj and they decided to leave, the most common form was karri-re. The resulting paradigm shape as a consequence of the collapsing between karri- and kane- is illustrated in Table 9. Note that the loss of the 12 ua distinction means that there is no need to continue with the min I ua I aug analysis:

Table 9. Young people's prefixes in Mamardawerre 1.

\begin{tabular}{|c|c|c|c|}
\hline \multicolumn{4}{|c|}{ Intransitive pronominal prefixes } \\
\hline & $\mathbf{s g}$ & $\mathbf{d u}$ & $\mathbf{p l}$ \\
\hline 1.excl & $(n g) a-$ & $(n g) a n e-$ & $(n g)$ arri- \\
\hline $\mathbf{1 . i n c l}$ & & $(n g) a r r-$ & karri- \\
\hline $\mathbf{2}$ & $y i-$ & yine- & yirri- \\
\hline $\mathbf{3}$ & $(\mathrm{ka}) \emptyset-$ & $(\mathrm{ka})$ bene- & $(\mathrm{ka})$ birri- \\
\hline
\end{tabular}

The neutralisation of $12 \mathrm{ua}$ is also found in the transitive prefixes, such that $12 \mathrm{ua}>3 \mathrm{nsg}$ often syncretises in form with $1 \mathrm{a}>3 \mathrm{nsg}, 12 \mathrm{~m}>3 \mathrm{nsg}$ or $12 \mathrm{a}>3 \mathrm{nsg}$. In examples (12) and (13), the speakers provide two different pronominal forms to the same $12 \mathrm{ua}>3 \mathrm{du}$ elicitation task: the first syncretising 12ua $>3 \mathrm{du}$ with the canonical 1a $>3 \mathrm{du}$ form ((ng)arrbenbene) and the second syncretising with the canonical 12a $>3 \mathrm{du}$ form (karrbenbene-):

(12) Ngalkodjok ngalbangardi ngarrbenbene-kadjun SKIN.NAME SKIN.NAME 12ua >3du-follow.NP "Ngalkodjok albangardi and I followed them (two)"

BKC_Marley_Conrad_prns

(13) Nuk ngurri-bengkan karribenbene-nang ngaye wurdurd boken INTERJ 2a-remember.NP 12ua > 3du-see.PP 1sg.DIR children two "Maybe, do you remember when we saw those two kids?"

BKC_Marley_Enosh

As speakers have neutralised 12 ua in different directions, there is some variety as to the direction of neutralisation in individual speakers' paradigms. Table 10 aggregates the $1>3$ transitive forms attested by Generation 3 speakers. Not only is kane- and its anticipated accompanying transitive forms (kaneben-/kanebenbene-) not attested, but there is neutralisation across clusivity boundaries, which further muddies semantic distinctions between first persons. As such, 12ua $>3 \mathrm{pl}$ is usually realised as either (ng)arrben- or karrben-, and (ng)arrben- could mean either $1 \mathrm{a}>3 \mathrm{pl}, 12 \mathrm{~m}>3 \mathrm{pl}$ or $12 \mathrm{a}>3 \mathrm{pl}$ : 
Table 10. Neutralisation in transitive first person subject pronominal prefixes by Gen 3 .

\begin{tabular}{|c|c|c|c|c|}
\hline & & \multicolumn{3}{|c|}{ OBJECT } \\
\hline & & $3 \operatorname{sg}($ (ø) & $3 \mathrm{pl}$ & $3 d u$ \\
\hline \multirow{6}{*}{ 它 } & $1 \mathrm{~m}$ & $(n g) a_{-}$ & $(n g) a b e n-$ & (ng)abenbene- \\
\hline & 1ua & (ng)ane-/(ng)arri- & (ng)aneben-/(ng)arrben- & $\begin{array}{l}\text { (ng)anebenbene-1 } \\
\text { (ng)arrbenbene- }\end{array}$ \\
\hline & 1a & (ng)arri-/karri-/(ng)arr- & (ng)arrben- & (ng)arrbenbene- \\
\hline & $12 \mathrm{~m}$ & (ng)arr-/(ng)arri- & \multirow{3}{*}{$\begin{array}{l}\text { (ng)arrben-/ } \\
\text { karrben- }\end{array}$} & \multirow{3}{*}{$\begin{array}{l}\text { karrbenbene-/ } \\
\text { (ng)arrbenbene- }\end{array}$} \\
\hline & 12 ua & \multirow{2}{*}{ karri-/(ng)arri- } & & \\
\hline & $12 a$ & & & \\
\hline
\end{tabular}

An outcome of this variation is numerous pronominal paradigms in circulation at once in the community. Not only are regularisation and neutralisation occurring, but there are also regional differences in pronominal prefix vowels. This is in addition to the initial-engma deletion and intraspeaker variation (as seen in Table 10) in regularisation, neutralisation and engma deletion. This results in an astounding number of possible combinations and consequently paradigm shapes. ${ }^{7}$ Table 11 combines into a single matrix all the attested forms in the BKC. Here, the initial engma variable is noted in brackets, while the regionally circumscribed vowels (e.g., bene-/bani-/bini- for 3ua) are replaced with " $\mathrm{V}^{\text {". }}$ In cases where two (or more) adjacent pronominal functions have the same form(s) (e.g., $2 \mathrm{~m}>1 \mathrm{sg}$ and $2 \mathrm{~m}>1 \mathrm{pl}(\mathrm{kan}-)$, the cells have been collapsed into a single cell to indicate syncretism. In many cells, there is variation in form and so multiple prefixes are included (e.g., $1 \mathrm{~m}>2 \mathrm{du}=b V n b V n V-/ \varnothing-/ b i$-). Finally, there are instances om wjocj the same form appears in multiple cells that are not necessarily adjacent to one another or in combination with the same variants. $B V n b V n V$-, for example, has at least four semantically distinct functions-3m $>3 \mathrm{du}, 1 \mathrm{~m}>2 \mathrm{du}$, 1ua $>2 \mathrm{du}$, and $1 \mathrm{a}>2 \mathrm{du}$ - but it does not co-occur with the same variants across these functions. In short, massive variation is presented, not only in the form and function of pronominals but also in the syncretism, all of which allows for multiple concurrent pronominal paradigms to coexist in the community-a situation that I call paradigmatic pluralism.

The obvious question that arises here is how this considerable semantic variation in the pronominal prefixes affects comprehension. In many instances of ambiguity, person reference markers external to the verbal complex, such as free pronouns, skin names ${ }^{8}$ and kin terms, providing Bininj with the option of specification when necessary. In example (14), the speaker uses free pronouns (ngarrewoneng and ngaye) to clarify number and clusivity, which are unspecified in the prefix ngandi-:

(14) Ngandi-bukkani ngarrewoneng Ngalwamud dja ngaye 3nm $>1$ nsg-show.PI 1uaOBL FE-skin.name CONJ 1sg.DIR

"They used to show us two, Ngalwamud and me." 
Table 11. All attested pronominal prefix forms.

\begin{tabular}{|c|c|c|c|c|c|c|c|c|c|}
\hline & \multicolumn{9}{|c|}{ OBJECT } \\
\hline SUBJECT & $\begin{array}{l}\text { INTRANS./ } \\
\text { 3sg (0-) }\end{array}$ & $3 \mathrm{pl}$ & $3 d u$ & 1 sg & 1pl & $1 \mathrm{du}$ & $2 \mathrm{sg}$ & $2 \mathrm{pl}$ & $2 \mathrm{du}$ \\
\hline $1 \mathrm{~m}$ & $(n g) a-$ & $(n g) a b V n-$ & $(n g) a b V n(b V n V)-$ & - & - & - & ø- & $\begin{array}{c}\varnothing-/ b V n-/ \\
b i-\end{array}$ & $\begin{array}{c}b V n b V n V-/ \\
\varnothing-/ b i-\end{array}$ \\
\hline 1ua & $\begin{array}{l}\text { (ng)anV-/ } \\
(n g) \text { arr-/ } \\
(n g) \text { arri- }\end{array}$ & $\begin{array}{l}(n g) a n V b V n-/ \\
(n g) \operatorname{arr}(i) b V n-\end{array}$ & $\begin{array}{l}(n g) a n V b V n(b V n V)-/ \\
(n g) \operatorname{arr}(i) b V n(b V n V)-\end{array}$ & - & - & - & (ng)undi-/ & (ng)undi-/yindi-/ & (ng)undi-/yindi-/kundi-/ \\
\hline $1 \mathrm{a}$ & (ng)arri-/(ng)arr- & \multirow{2}{*}{$\begin{array}{l}(n g) \operatorname{arr}(i) b V n-/ \\
\text { karr(i)bVn- }\end{array}$} & $(n g) \operatorname{arr}(i) b V n(b V n V)-$ & - & - & - & yindi- & kundi-/bi- & $b i-/ b V n b V n V-$ \\
\hline $12 \mathrm{~m}$ & $\begin{array}{c}\text { (ng)arr-/ } \\
\text { karri-/(ng)arri- }\end{array}$ & & $\begin{array}{c}(n g) \operatorname{arr}(i) b V n(b V n V-) / \\
k a r r(i) b V n(b V n V)-\end{array}$ & - & - & - & \multirow{3}{*}{\multicolumn{2}{|c|}{ - }} & - \\
\hline 12 ua & $\begin{array}{c}\text { kanV-/ } \\
\text { karri-/(ng)arri- }\end{array}$ & $\begin{array}{c}\text { kanVbVn-/ } \\
(n g) \operatorname{arr}(i) b V n-/ \\
\text { karr }(i) b V n-\end{array}$ & $\begin{array}{c}\text { kanVbVn(bVnV)-/ } \\
(n g) \operatorname{arr}(i) b V n(b V n V)-/ \\
\text { karr(i)bVn(bVnV)- }\end{array}$ & - & - & - & & & - \\
\hline $12 \mathrm{a}$ & karri-/(ng)arri- & $\begin{array}{l}\text { karr(i)bVn-/ } \\
(n g) \operatorname{arr}(i) b V n-\end{array}$ & $\begin{array}{l}\text { karr(i)bVn(bVnV)-/ } \\
(n g) \operatorname{arr}(i) b V n(b V n V-)\end{array}$ & - & - & - & & & - \\
\hline $2 \mathrm{~m}$ & $y i-$ & yibVn- & yibVn(bVnV)- & \multicolumn{2}{|l|}{ kan- } & $\begin{array}{c}\text { kan-/ } \\
\text { kanbVnV- }\end{array}$ & \multirow{3}{*}{ - } & \multirow[t]{2}{*}{ - } & - \\
\hline 2 ua & $\begin{array}{c}\text { (ng)unV-/ } \\
\text { (ng)urri- } \\
\text { kunV-/yinV- }\end{array}$ & $\begin{array}{l}\text { (ng)unVbVn-/ } \\
\text { (ng)urr(i)bVn-/ } \\
\text { yinVbVn-/ } \\
\text { yirr(i)bVn- }\end{array}$ & $\begin{array}{l}\text { (ng)unVbVn(bVnV)-/ } \\
(n g) u r r(i) b V n(b V n V)-/ \\
\text { yinVbVn }(b V n V)-/ \\
\text { yirr(i)bVn(bVnV)- }\end{array}$ & \multirow{2}{*}{$\begin{array}{l}\text { kandi-/ } \\
\text { (ng)andi- }\end{array}$} & \multicolumn{2}{|r|}{$\begin{array}{l}\text { kandi-/ } \\
\text { (ng)andi- }\end{array}$} & & & - \\
\hline $2 a$ & $\begin{array}{l}\text { (ng)urri-/ } \\
\text { kurri-/ } \\
\text { yirri- }\end{array}$ & $\begin{array}{l}(n g) u r r(i) b V n-/ \\
\text { yirr(i)bVn- }\end{array}$ & $\begin{array}{c}(n g) u r r(i) b V n(b V n V)-/ \\
y(i) b V n(b V n V-\end{array}$ & & & kandi- & & - & - \\
\hline $3 m$ & $(k a) \varnothing-/ b a-, b i-$ & $(k a) b V n-$ & $\begin{array}{c}\text { (ka)bVnbVnV-/ } \\
\text { (ka)bVn- }\end{array}$ & $\begin{array}{c}\text { (ng)an- } \\
\text { kan- }\end{array}$ & & $\begin{array}{c}\text { kan-/ } \\
\text { kanbVnV-/ } \\
(n g) a n b V n V-\end{array}$ & \multicolumn{2}{|c|}{ (ng)un-/yin-/kun- } & $\begin{array}{c}\text { (ng)unbVnV-/yinbVnV-/ } \\
\text { kunbVnV-/ } \\
\text { (ng)un-/yin-/kun- }\end{array}$ \\
\hline 3 ua & $(k a) b V n V-$ & \multirow{2}{*}{\multicolumn{2}{|c|}{ (ka)bVndi- }} & \multirow{2}{*}{\multicolumn{3}{|c|}{ (ng)andi-/kandi- }} & \multirow{2}{*}{$\begin{array}{l}\text { (ng)undi- } \\
\text { yindi- }\end{array}$} & \multirow{2}{*}{$\begin{array}{l}\text { (ng)undi-/bi- } \\
\text { yindi- }\end{array}$} & \multirow{2}{*}{$\begin{array}{l}\text { (ng)undi-/kundi-/yindi- } \\
\text { (ng)unbVnV-/kunbVnV- }\end{array}$} \\
\hline $3 a$ & (ka)bVrri- & & & & & & & & \\
\hline
\end{tabular}


Although Bininj do clarify in this manner, ambiguous person reference may in fact be preferred. Garde (2013, p. 1) posits that there is a high tolerance for and even an expectation of vague and allusory person reference on the basis that "under-specification and circumspect reference" are culturally appropriate discourse norms. Heath (1991) also argued that there are sociocultural motivations for ambiguous person and number marking in the pronominal paradigm, citing pragmatic value in assigning irregular forms, particularly in first and second person combinations. In his view, the opacity of the 1 $<>2$ pronouns affords speakers a means to navigate delicate or taboo communicative scenarios without contravening social and cultural norms. Thus, imperatives, bad news or deference can all be respectfully signalled by playing down the addressee-speaker relationship by omission, substitution or skewing pronominal forms. As he puts it, "such irregular and problematic combinations are more, not less, highly valued than regularised alternatives would be; the latter would make life easier for grammarians, but more difficult for flesh-and-blood native speakers engaged in actual communicative acts" (Heath 1991, p. 86).

While this is a very attractive explanation, there is one rather large stumbling block. If person obfuscation were solely pragmatically motivated, we would expect parallel syncretism in the free pronouns (e.g., ngudda, ngudangke or ngudberre), which has not been found to occur (yet). A study of syncretism in Dalabon (Evans et al. 2001) revealed similar patterns of syncretism and, although syncretisms in Dalabon were historically likely to be pragmatically motivated, this is now a morphological concern as the patterns are grammaticalised to specific areas of the transitive pronominal paradigm. Thus, what may have begun as a fairly ordered process has became less transparent over time, with the directionality of the syncretism remaining similar but the rules of referral becoming inconsistent between speakers.

\subsection{Borrowing}

Buffalo traders came to the East Alligator River region in the 1870s, marking the introduction of English (or at least pidgin English) to the country of Gaagudju, Ngaduk, Amurdak, Giimbiyu and Kunwok (Kundjeyhmi) languages. Contact with Kriol is much more recent. Generally associated with the Kimberleys, WA and the Katherine and Roper River regions of the NT, Kriol is the second largest language in the NT after English, with around 20,000 speakers (Australian Bureau of Statistics 2016). It has been expanding in range (Dickson 2016) and is now the primary language in southern Arnhem Land and the neighbouring Roper River area, as many of the traditional languages of the region, such as Jawoyn, Dalabon, Rembarrnga, Ngalakgan, Wubuy, Marra, Mangarrayi and Alawa, are no longer spoken or have very few fluent speakers left (Battin et al. 2020).

At a glance, English and Kriol loanwords in Kunwok appear to be on the rise. The BKC was surveyed for instances of loanwords which were then cross-tabulated with the speaker's date of birth. Note that while there was an occasional word from languages other than English and Kriol (e.g., Mawng), these were far too few in number to investigate further. Loanword counts can be measured in two ways: first, by the raw number of tokens that are encountered in the dataset, and second, by counting the number of distinct loanwords. For instance, the most frequently attested loanword, muddika, "car", occurs 78 times in the corpus but is only one of a total of 816 English/Kriol loans attested. In terms of the proportion of borrowing, Generation 3 (1977-2010) ranked significantly higher than the generations that preceded them (15\% of their data were loanwords), but varied very little from Gen 2 in terms of the number of loaned items (469 individual loan words vs. 442) (Table 12): 
Table 12. Loanword tokens as a percentage of speech data and loanword count.

\begin{tabular}{ccc}
\hline Gen & Tokens & Loans \\
\hline 1 & $3 \%$ & 218 \\
2 & $8 \%$ & 469 \\
3 & $15 \%$ & 442 \\
\hline
\end{tabular}

The majority of loans are nouns accompanying imported cultural concepts and artefacts, such as "car" (muddika) and "cat" (budjiked). The earliest loans from English have often been fully phonologically incorporated into Kunwok ("pussycat" $\rightarrow$ budjiket), but this process is far from predictable or systematic, as Poplack (2018) has established in her work on French-English contact effects in Canada. For instance, the word "mission", mishin, stubbornly retains its sibilant in all instances attested in the BKC, despite being a common loanword in the early days of contact, while the /s / in "pussycat" is faithfully transformed into the palatal stop $/ \mathrm{c} /(\langle\mathrm{d} j\rangle)$. Additionally, not all loanwords were directly imported from English but came via a neighbouring language. This is particularly true of Makassan loans, many of which entered Kunwok via the Iwaidjan languages (Evans 1992). Some of the loans can be considered "gratuitous" (Haspelmath 2009) in that such loans are synonymous with already existing Kunwok words. For example, the verb "to help" is the most frequently borrowed loan verb (either from English "help" or Kriol helbam) in the corpus $(\mathrm{n}=17)$, outranking the Kunwok verb of the same meaning bidyikarrme ( $\mathrm{n}$ $=9$ ). In examples (15) and (16), two speakers are retelling the same story (based on an elicitation tool by O'Shannessy 2004) but employ different ways of saying "help". The first uses the Kunwok bidyikarrme, while the second uses the English "help" accompanied by the Kunwok verb yime, "do/say", to form a periphrastic verbal construction.

(15) Nani djarrang karri-bidyikarrme

MA.DEM horse 12a-help.NP

"Let's help the horse"

BKC_Marley_Alexandria

(16) Then ngalbadjan nakornkumo help bini-yimeng then mother father help 3ua-do.PP

"Then the mother and the father helped him"

BKC_Marley_Kiara_2

This second strategy is the preferred manner of incorporating loan verbs in Australian languages, particularly in non-Pama-Nyungan languages (Wohlgemuth 2009). It typically involves an uninflected loan verb (the coverb) carrying the semantic weight of the complex predicate accompanied by a recipient language verb (the light verb) which has been semantically bleached but hosts the inflectional morphology (McGregor 2013; Meakins and O'Shannessy 2012; Schultze-Berndt 2000). This loan verb integration strategy is one of three possible ways to borrow verbs. The most common cross-linguistically is by direct insertion, whereby a loan verb is brought into the recipient language with no morphosyntactic accommodation (Wohlgemuth 2009) (example (17)). The second is the coverb strategy (example (18)). The third method, which is also attested in Kunwok, is by indirect insertion, in which the donor verb is affixed with some sort of verbalising element to nativise it (example (19)).

(17) Direct insertion example in German (from English loan)

$$
\begin{aligned}
& \text { Wir klick-en } \\
& \text { 1pl.NOM click-PRES.1pl } \\
& \text { "We click" }
\end{aligned}
$$


(18) Coverb insertion example in Italian (from English loan)

Fai clic ed ascoltare

do.2sg.PRES click and listen.INF

"Click and listen"

(19) Indirect insertion example in Greek (from English loan)

\author{
Klik-ár-o \\ click-VBSR-1sg \\ "I click"
}

Kunwok speakers use two of these strategies to integrate borrowed verbs-coverb constructions and indirect insertion-with younger speakers showing a stronger preference for the coverb strategy than the previous generations (see Figure 4). Wohlgemuth's (2009 p. 147) global survey of loan verbs indicated that using multiple strategies to accommodate verbs is not uncommon ( $26.7 \%$ of his sample, $\mathrm{n}=352)$, and that in Australia, the two preferred methods are coverb constructions and indirect insertion. As a regular feature in Australian languages, coverb constructions frequently feature as the primary verbal structure: $90 \%$ of Gurindji (Pama-Nyungan) verbal structures, for example, are coverb constructions (Bowern 2014, p. 278). Kunwok, however, only uses this construction for loans, and in fact, coverb constructions are heavily implicated in contact scenarios, with the phenomenon in Australia particularly concentrated near the Pama-Nyungan-nonPama-Nyungan border (Bowern 2014). Of the Gunwinyguan languages, only Kunbarlang employs coverbs for native elements (Kapitonov 2019), indicating that coverbs are not an inherent feature of Gunwinyguan languages but rather a consequence of contact. ${ }^{9}$

There are only three attested light verbs in Kunwok, giving it one of the smallest light verb inventories documented in an Australian language (Bowern 2014). The most common verb used as a light verb is "do/say", yime, with 175 of 201 (87\%) coverb constructions in the BKC employing it. The other two verbs, "go", re, and "carry/take", kan, are far less frequent, with re attested 24 times $(12 \%)$ and kan only twice, both times by the same speaker.

Generational verb constructions

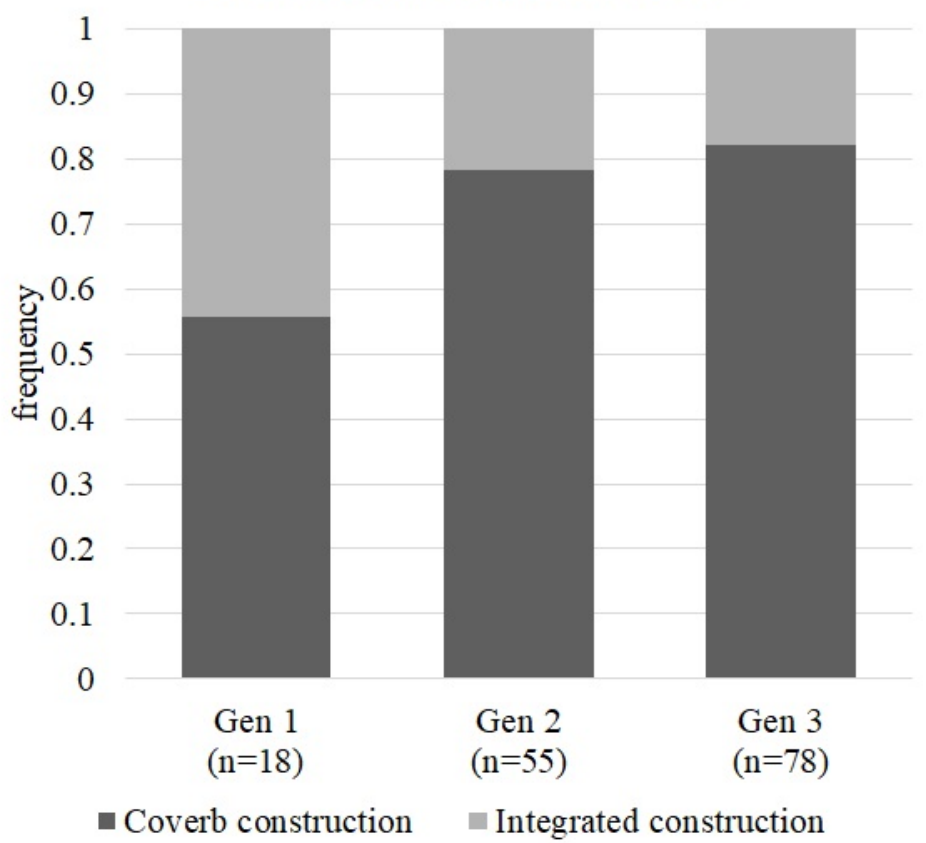

Figure 4. Distribution of coverb strategy and indirect insertion strategy across three generations. N = number of speakers. Gen 1: 1907-1944, Gen 2: 1945-1976, Gen 3: 1977-2010. 
Loan verbs that are inserted indirectly are suffixed with the verbaliser - $(h) m e^{10}(\mathrm{ex}-$ amples (20) and (21)) and will inflect according to the paradigm for verbs ending in -me. There were far fewer tokens and examples of verbs borrowed this way, and they tend to be verbs that were borrowed in the early days of contact, such as "buy" and "work" (examples (20) and (21)). Nonce examples of indirectly incorporated verbs were provided by a couple of speakers during an interview on the topic (examples (22) and (23)). Note that these examples use Kriol verbs, identifiable by the Kriol transitive suffix -im (examples (22) and (23)).

(20) English: 'buy' + -hme

Baleh kore bene-baya-hmeng?

Where LOC 3ua > 3sg-buy-VBSR.PP

"Where did they buy it from?"

PARADISEC_CC01-000-BWALKCOMMS0_S8

(21) English: 'work' +-hme

Dja kunu bedman-ni stockman barri-woki-hmi kunu

CONJ in.that.way 3a-PI stockman 3a-work-VBSR.PI in.that.way

"So those stockmen used to work like that"

BKC_Garde_Bokmarnde_Nlo

(22) Kriol: daunlodim 'download' + -me

Nga-dawnlodim-meng korroko

$1 \mathrm{~m}$-download-VBSR.PP before

"I already downloaded it"

Marley_fieldnotes20180826

(23) Kriol: bilimab 'fill' + -me

Yi-bilimab-men

$2 \mathrm{~m}>3$ sg-fill.up-VBSR.IMP

"Fill it up!"

Marley_fieldnotes20170426

The sample size presented here is too small to draw any solid conclusions about changes in the way loan verbs are integrated into Kunwok, but of the 194 tokens of coverb constructions in the corpus, $57 \%$ were produced by Gen 3 (Figure 5). This provides a preliminary indication that coverb constructions are on the rise in Kunwok.

\section{Coverb constructions $(n=194)$}

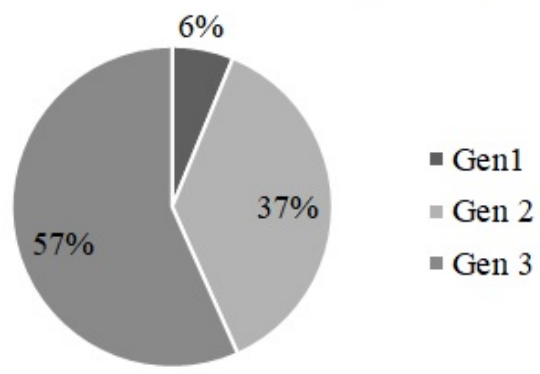

Figure 5. Coverb strategy use by three generations. 
A similar rise in the adoption of complex predicates has also been observed in Murrinhpatha, where Mansfield (2014, p. 420) noted an increase in coverb constructions with English loan verbs, especially in the speech of young men. Murrinhpatha, like Kunwok, is a highly synthetic non-Pama-Nyungan language, with children still learning it as a first language, but the documented rise of coverbs in Murrinhpatha differs to that observed in Kunwok in that there are a number of Murrinhpatha verbs (albeit limited) that ordinarily take the form of the coverb plus light verb construction. Additionally, Murrinhpatha very rarely incorporates borrowed verbs into the synthetic verb complex (Mansfield found only a single example) on the basis that the other verbal elements and verb roots are too rigid and opaque to allow for the insertion of novel borrowed forms.

Comparative and historical analyses of the verbal morphology of Australian languages have demonstrated that verbs in Northern Australia follow a cyclical evolutionary path, transforming from synthetic to phrasal structures and eventually back again (Dixon 2002; Schultze-Berndt 2003). Grammaticalisation and phonological erosion generally underlie this process; however, contact may also play a role in some cases. With respect to Murrinhpatha, Mansfield (2016, p. 356) argues that contact has facilitated a turn in the cycle. The same hypothesis is not advanced for the neighbouring Daly River language Ngan'gityemerri. Ngan'gityemerri has undergone some radical morphosyntatic restructuring to its verbal complex in the past century, which Reid $(2003$, p. 120) argues is unrelated to contact with English. In Kunwok, the rise of the coverb in young people's speech may signal a similar incipient turn of the evolutionary wheel, but whether this is as a direct response to English/Kriol contact (as with Murrinhpatha) or a coincidence (as with Ngan'gityemerri) requires further investigation.

\section{Attitudes and Perceptions}

In addition to examining the objective mechanisms and manifestations of language change, we need also to consider the subjective correlates; that is, the sociopsychological facets of the variable. By examining speaker perspectives on language change and the variables-in particular, assessing salience and accessing the unconscious reactions-we can determine the likelihood that the variables in question are indicative of a change in progress. This approach is taken from Labov (1965), who noted that speaker evaluations are critical to measuring a variable's propensity for change; in short, if there is no commentary on the variable, then it is below the consciousness of speakers and therefore likely to be a change in progress phenomenon.

The linguistic features identified as prevalent in young people's Kunwok differed greatly in terms of their salience to speakers. During my fieldwork (conducted 20152019), eliciting a discussion about the initial engma deletion often proved futile, with most speakers unable to engage in the topic. This contrasts to the experience of Evans (2003), who, in the late 1980s and early 1990s, found that his consultants could readily discuss the regional distribution of initial engma deletion (typically associated with Mayali) but would deny having produced the feature themselves.

One particular interaction during my fieldwork did reveal one interesting insight into community interpretations of dropping the velar nasal. The following English-Kunwok conversation occurred between me (AM) and a girl of around 10 years (NK):

(24) NK: What do I call you again? 'Karrang'? mother.VOC

What do I call you again? "Mum"?

AM: Larrh, 'djedje'. Ngudda Ngal-kangila, yoh? NEG daughter 2sg.DIR FE-skin.name yes

No, "daughter". You're Ngalkangila, right? 
NK: Eh?

AM: Ngaye Ngal-kodjok, ngudda Ngal-kangila... so 'Djedje'.

1sg.DIR FE-skin.name 2sg.DIR FE-skin.name so daughter

I'm Ngal-kodjok, you're Ngal-kangila... so "daughter".

NK: Eh! AL-kangila. NA-kangila, that's a boy.

AM: Yoh, but like, NGAL-kangila and AL-kangila same like. You can say Ngal-kangila or Al-kangila... right? Like, same.

(PAUSE)

NK: Hmmm, but like, we say AL-kangila. NGAL-kangila sounds like a boy, NA-kangila. Used to be Ngal-kangila, but now it's Al-kangila. Old people say Ngal-kangila.

Marley_fieldnotes20161028

This conversation suggests that, for this child, the absence of an initial nasal is a salient feature of the FE gender prefix, which serves to increase the distinction between MA (na-) and FE (ngal-). While this perception was only documented in one child, it indicates, along with the general low engagement on the topic, that the social meaning of engma deletion is changing. Not only is it no longer or rarely associated with a regional distribution, but it is now correlated with age and has moved below the level of consciousness for most speakers. In this case then, we have statistical evidence that there is a sound change in progress, and also socio-psychological indications that this particular variable has shifted in social meaning.

Pronoun variation, meanwhile, was a matter of discussion and even a feature which was captured as being corrected and argued over by children. The following disagreement was documented during one of my early language lessons:
AM: So if I want to say "you two caught a file snake"? Ngune-ngalkeng kedjebe? Kamak? [2ua-find.PP file.snake right]
EN: Yine-ngalkeng kedjebe
ED: YI:NE:-ngalkeng kedjebe
AM: Ah, YINE-ngalke-
TM: (interrupting) NGUNE-ngalkeng kedjebe!
ED: YINE-!

Marley_fieldnotes20160905

Here, two girls, EN and ED (both aged 11 years), corrected my pronominal prefix ngune- with their preferred regularised form yine-. Their younger relative, TM, (M, 7 years) overheard this and loudly disagreed, insisting that the correct form is the irregular ngune-. Interestingly, this boy's father (Conrad) is the very same Gen 2 man reported in Section 3.2.1 who regularises second person. Conrad (b. 1972) uses both the traditional and regularised second person forms, and his "youthful" way of speaking is sometimes the subject of mirth, especially for his wife and her mothers. He is also aware of his style of speech, commenting that the "proper way" is ngurri-, not yirri-. Adults also reported trying to redress regularisation in younger speakers. One 44-year-old woman provided the following account of a failed attempt to "correct" her 19-year-old daughter (Lorina): 
(26) Rosemary on the topic of correcting her daughter's regularised second person prefixes:

A-yime, 'hey makka man-wid!' ... Aye ngan-kayime 'oh, $1 \mathrm{~m}>3$ sg-say.NP hey VEG.DEM VEG.wrong 1 sg.DIR $3 \mathrm{~m}>1$ sg-say.NP oh a-wokdi mani kunwok arduk nga-wokdi'. 'Larrk' nga-yime! $1 \mathrm{~m}$-speak.NP MA.DEM language 1sg.OBL 1m-speak.NP no $1 \mathrm{~m}$-say.NP

"I say to her, 'hey, that's wrong!' ... She says to me, 'oh I speak language my way'. 'No!' I say."

Marley_Rosemary001_20161103

Despite this report of prescriptivism, the only instances directly observed of adults correcting children were limited to kin terms, which is not unsurprising as kinship is central to the Bininj social framework, and all interactions are conducted through the lens of classificatory and consanguineal relationships. Deviating from the commonly agreed norms in this regard has an actual social penalty (e.g., shame or causing insult) unlike the other points of linguistic variation.

Discrepancy between overtly expressed beliefs about language use and actual behaviour are generally a sign that linguistic ideologies are at play (Singer and Harris 2016). In Bininj communities, that there is extensive variation coupled with few communicative and social consequences points towards a general mindset and attitude that is favourable to language variation and change. Lorina's stance that "she speaks her language her way" encapsulates a community-held belief in individual autonomy, which encourages linguistic diversity and pluralism. This open linguistic ideology extends to changes and variation that may occur as a result of contact. Conrad, when pressed further for his views on variation and change in Kunwok, said the following:

(27) Dabbarrabolk kun-rayek kun-wokdanj. So to us mob new generation it's too hard for us to understand what kun-rayek was spoke. Because, like English understand arri-yime well than what kun-rayek and then try ngad arri-marnbun kunwok, the way English are said. Cos like what you written down there today it's almost mixed with English, but that's how it's said.

“Old people spoke strong language. But for us new generation, it's too hard to understand that old way of speaking. Because, like, we understand English better than the old language, and then when we try and speak it, it sounds like English. What you've been writing down today, that's almost mixed with English, but that's how we speak."

BKC_Marley_CM2_kunwinglish_20180826

Conrad's comments on the language of previous generations and the modern trend of mixing English and Kunwok were echoed by many in the community. However, although community members focused on obvious contact effects, any changes (regardless of origin) to the phonology or structure of the language were deemed secondary compared to the potential pragmatic repercussions. Monitoring and assessing changes to social and culturally centred aspects of language such as triadic kin terms ${ }^{11}$ and mother-in-law language ${ }^{12}$ have far more priority than the actual form of the language, and there is considerable concern that these elements are no longer being learned by children. The loss of these sociolinguistic devices cannot necessarily be pinned on contact however, and older community members are mindful of this, putting forward arguments that children and youth need to learn "both ways"; i.e., Bininj culture and language and Balanda ${ }^{13}$ culture and language. 


\section{Modern Kunwok and Kunwinglish}

We have seen that the scope of variation and change in Kunwok covers phonology to paradigms, but the features of young Bininj's speech presented here are not an exhaustive list of the changes and variation documented in the language. On its current trajectory, Modern Kunwok will lose initial engmas in closed-class morphemes, no longer have a $\min /$ ua I aug pronominal system and have a regularised second person prefix series. In addition to these, there is evidence of clusivity neutralisation in pronouns, variation in TAM suffixes on verbs, variation in stative and dynamic verbs (e.g., ni-, "be sitting" yerrkan, "sit down"). There are also reports by some speakers of the apicalisation of retroflex nasals (e.g., benefactive prefix marne- $\sim$ mane-) and of the regularisation of Kunwok wordorder, which is largely non-configurational, but which some say children are standardising to SVO.

The levelling of some dialectal features (e.g., initial engma deletion) and regularisation are both heavily implicated in koineisation, the process by which speakers of different dialects converge in the way they speak (Siegel 2001). Dialectal homogenisation in Kunwok and the increasing use of English and Kriol loanwords is matched by the ongoing maintenance of Kunwok as an L1, pointing towards the potential development of a mixed language rather than a straightforward shift to English or Kriol. Evidence for the emergence of a mixed language is fragmentary but nevertheless cogent. For instance, some speakers incorporate loan nouns into the verbal structure, in what was reported by older speakers as a highly unusual but amusing practice. Here, in example (28), the speaker (F, 26 years) incorporates the loanword "bottle" bodel into the verbal structure as she gives instructions to her sister over the phone.

(28) Yi-m-djal-bodel-ma

2m-towards-just-bottle-bring.NP

"Just bring a bottle"

BKC_Marley_Carmen_prns

Incorporable nouns are generally a closed class, limited to body parts and highfrequency "generic" nouns such as "tree" $d u l k$, and "rock/stone" wardde, but this example demonstrates that speakers deem Kunwok flexible enough to absorb loans without the need to dramatically alter its morphosyntax. In another example, a child (F, 11 years) uses the Kriol adjective hotwan with Kunwok nominal morphology, instead of a full Kunwok expression (man-bo-wurlhwurlmi) or leaving the adjective outside the nominal complex as is generally done (kukku hotwan):

(29) Yoh man-bo-hot-wan yes VEG-liquid-hot-ADJ

"Yes, the water's warm"

BKC_Marley_fieldnotes20190221

In both cases, the predicates maintain Kunwok morphosyntax, but the loans have been fully integrated in ways that have not been observed in the speech data of Generations 1 or 2. Taken as isolated incidents, these instances may seem unconvincing; however, when coupled with the coverb loan incorporation strategy and a potential drift towards SVO word ordering, there is mounting evidence for an emerging mixed language.

Mixing English and Kunwok in this manner has already been given a name by some Mamardawerre community members - Kunwinglish — but unlike other -lish linguistic varieties (e.g., Singlish, Spanglish, Chinglish), this does not refer to a type of English. This informal moniker signals the legitimacy of this emerging code and reflects the community's philosophy of respecting linguistic autonomy and diversity and valuing a "both ways" approach to language and culture. Such open linguistic ideologies ensure that any nascent mixed language will likely be subject to the same flexible terms of use afforded its ancestral forms and continue to have extensive variation. 
Lastly, it is important that modern Kunwok or Kunwinglish is supported. As observed by Donaldson (2002) in her assessment of Ngiyampaa, and more recently pointed out by Dickson (2015) and O'Shannessy (2005), people find ways to express old ways of speaking in a new language. Hence, despite signs of regional levelling and contact-influences from Kriol and English, modern incarnations of the language can continue to facilitate the expression of cultural concepts.

Funding: This research was funded by an ARC Laureate grant (FL13100111) and the ARC Centre of Excellence for the Dynamics of Language (CE140100041).

Institutional Review Board Statement: The study was conducted according to the guidelines of the Declaration of Helsinki, and approved by the Human Research Ethics Committee of The Australian National University (HREC Protocol: 2014/224), 2014.

Informed Consent Statement: Informed consent was obtained from all participants involved in this study. The Australian National University HREC Protocol: 2014/224.

Data Availability Statement: The data presented in this study are available on request from the corresponding author. The data are not publicly available due to third party restrictions on sharing. Data obained from third parties are accessible through AIATSIS. Portions of the data are openly available in PARADISEC.

Acknowledgments: I am deeply indebted to the Bininj people of West Arnhem; in particular, the Mamardawerre community who hosted me and taught me Kunwok during my fieldwork. I also wish to acknowledge the Traditional Owners of Country throughout Australia and pay my respects to Elders past and present. Their custodianship has never been ceded.

Conflicts of Interest: The author declares no conflict of interest.

\section{Abbreviations}

The following abbreviations are used in this manuscript:

\begin{tabular}{ll} 
a/aug & Augmented \\
$\mathrm{m} / \mathrm{min}$ & Minimal \\
ua & Unit augmented \\
$\mathrm{nm} / \mathrm{nmin}$ & Non minimal \\
$\mathrm{sg}$ & Singular \\
$\mathrm{du}$ & Dual \\
$\mathrm{tri}$ & Trial \\
$\mathrm{pl}$ & Plural \\
$\mathrm{nsg}$ & Non singular \\
incl & Inclusive \\
excl & Exclusive \\
$\mathrm{SUB}$ & Subject \\
OBJ & Object \\
DIR & Direct \\
VOC & Vocative \\
CONJ & Conjunction \\
DEM & Demonstrative \\
INTERJ & Interjection \\
REL & Relative pronoun \\
IMM & Immediate \\
IMP & Imperative \\
NP & Non.past \\
PP & Past.perfect \\
PI & Past.imperfect \\
REDUP & Reduplication \\
IRR & Irrealis \\
VBSR & Verbaliser \\
\hline &
\end{tabular}




$\begin{array}{ll}\text { LOC } & \text { Locative } \\ \text { FE } & \text { Feminine } \\ \text { MA } & \text { Masculine } \\ \text { VEG } & \text { Vegetable } \\ \text { I } & \text { Noun class I } \\ \text { II } & \text { Noun class II } \\ \text { III } & \text { Noun class III } \\ \text { M } & \text { Mother } \\ \text { MM } & \text { Mother's mother } \\ \text { NOM } & \text { Nominal } \\ \text { INF } & \text { Infinitive } \\ \text { PRES } & \text { Present }\end{array}$

Appendix A. Bininj Kunwok Corpus

Table A1. Corpus metadata 1.

\begin{tabular}{lcccc}
\hline Collection & Items & Hours & Words & Rec. Years \\
\hline Berndt \& Berndt & 1 & NA & 1766 & 1951 \\
Bird & 9 & $01: 13: 17$ & 2289 & $2016-2019$ \\
Carroll & 39 & $01: 53: 54$ & 5938 & $1973-1976$ \\
Cialone & 24 & $03: 28: 53$ & 4610 & $2015-2016$ \\
Evans & 32 & $01: 13: 17$ & 4954 & $1987-1999$ \\
Garde & 14 & $01: 48: 15$ & 6087 & $2010-2015$ \\
Hale & 6 & $00: 48: 56$ & 2665 & 1959 \\
Kinslow-Harris & 2 & $00: 14: 15$ & 785 & 1965 \\
Marley & 67 & $12: 36: 31$ & 8734 & $2016-2019$ \\
Oates & 5 & NA & 970 & 1964 \\
Peters & 2 & $00: 10: 02$ & 297 & 1970 \\
Ponsonnet & 7 & $01: 05: 05$ & 3121 & $2016-2017$ \\
Aung Si & 4 & $00: 44: 59$ & 2434 & 2014 \\
Singer & 14 & $02: 17: 32$ & 4068 & 2016 \\
\hline total: 14 & 226 & $27: 34: 56$ & 48,718 & \\
\hline
\end{tabular}

Table A2. Corpus metadata 2.

\begin{tabular}{ll}
\hline Speakers: & $98 \quad$ M: 63 F: 45 \\
D.o.B range: & $1907-2011$ \\
Age range: & $6-\sim 80$ years old \\
& Narratives, procedurals, visual-aid elicitations, \\
Genres: & sentence elicitations, plant descriptions, \\
& landscape description and tours \\
\hline
\end{tabular}

\section{Notes}

1 The BKC was developed with the support of CoEDL's corpus project: http:/ / www.dynamicsoflanguage.edu.au/ research/language-diversity/corpus-development/ .

2 See Appendix A for more on the corpus content.

3 These dates also conveniently correspond to significant historical events: the end of World War II (1945) and the "outstations movement" - the decentralising migration of peoples away government and missionary settlements back to traditional homelands, prompted by a government shift in Australian Indigenous policy towards selfdetermination (1972) and the Northern Territory Land Rights Act (1976) (?). Many thanks to an anonymous reviewer for noticing this.

4 One exception to this is the word for 'buffalo' nganabbarru, a loanword. For a full exegesis, see Marley 2020.

5 Calculated with a simple linear regression.

6 These are, as listed by Dixon (2002), Rembarrnga, Dalabon, Jawoyn, Kunbarlang, Kungarakany, Gaagudju, Burarra, Gurrgoni, Ndjébbana, Nakkara, Ngandi, Wagiman and Wardaman.

7 See (Marley 2020) for more expansive discussion of this. 
8 A "skin name" is a classificatory name inherited through the female line. There are eight skin name male and female pairs in total, divided along lines of matrimoiety and patrimoiety. This system forms the basis of all relationships, marriages, kinship obligations and interactions in general in Bininj society.

9 Having said this, several Gunwinyguan languages (e.g., Ngalakgan, Rembarrnga and Mangarrayi) exhibit coverb-like constructions where a "prepound" (a sort of adverbial or semantic modifying element) is sometimes "excorporated" (Baker 2014, p. 147) from the main verb stem (the "thematic"), resulting in a periphrastic construction closely resembling a coverb structure; e.g., Rembarrnga: (1) yarra-ngeh-miny [1a-get.up-PP] “We got up" vs. (2) ngeh barrayappah-many [get.up 3a-ua-went] "They two got up" (Saulwick 2003, p. 116f). This may be an instance of Rembarrnga being at a different stage of the verb evolutionary cycle (Dixon 2002). Many thanks to two anonymous reviewers for bringing this to my attention.

10 The glottal stop $\langle\mathrm{h}\rangle$ is only found when the verbalised root does not end in a stop (Evans 2003, p. 343). Additionally, $-m V$ is a widespread suffix in Australia used for creating transitive verbs. While most loan verbs ending in - $m e$ are transitive, "to work", wokihme, is one exception. Conversely, in Kunwok, the majority of native verbs ending with -me are generally intransitive (e.g., wurlebme, "bathe/wash/swim") and often have a corresponding transitive form ending in -ke (e.g., wurlebke, "immerse something in water/wash something"). For a further discussion on transitivity and loan verbs in Australia, see Simpson (2016).

11 These are referential kin terms that combine into a single term the relationships between three people; e.g., when I am talking to my mother about her brother.

12 Mother-in-law language is a respect register used by a man in the presence of his mother-in-law (or woman and her son-in-law). It is a common feature of Australian Aboriginal societies.

13 Balanda (from Makassarese belanda "Dutchman"; i.e., "Hollander") is a wanderwort of north Australia meaning "nonAboriginal". Here, I use it to refer to the dominant white Anglo-Celtic Australia.

\section{References}

Alpher, Barry. 1976. Some linguistic innovations in Cape York and their sociocultural correlates. In Languages of Cape York Peninsula. Edited by Peter Sutton. Canberra: Australian Aboriginal Studies, AIAS, pp. 84-101.

Amery, Rob. 1985. A New Diglossia: Contemporary Speech Varieties at Yirrkala in North east Arnhem Land. Master's thesis, The Australian National University, Canberra, Australia. [CrossRef]

Australian Bureau of Statistics. 2016. Language Spoken at Home by Sex (SA2+). Available online: http://stat.data.abs.gov.au/Index. aspx?DataSetCode=ABS_C16_T09_SA (accessed on 1 March 2020)

Baker, Brett. 2014. Word structure in Australian languages. In The Languages and Linguistics of Australia. Edited by Harold Koch and Rachel Nordlinger. Berlin: Mouton de Gruyter, pp. 139-213.

Battin, Jacqueline, Jason Lee, Douglas Marmion, Ronda Smith, Tandee Wang, Yonatan Dinku, Janet Hunt, Francis Markham, Denise Angelo, Emma Browne, and et al. 2020. National Indigenous Languages Report. Technical report. Canberra: AIATSIS.

Berndt, Catherine H., and Ronald M. Berndt. 1951. An Oenpelli Monologue: Culture-contact. Oceania 22: 24-52. [CrossRef]

Blevins, Juliette. 2001. Where have all the onsets gone? Initial consonant loss in Australian Aboriginal languages. In Forty Years on: Ken Hale and Australian Languages. Edited by Jane Simpson, David Nash, and Mary Laughren. Canberra: Pacific Linguistics, pp. 481-92. [CrossRef]

Bowern, Claire. 2014. Complex Predicates in Australian languages. In The Languages and Linguistics of Australia. Edited by Harold Koch and Rachel Nordlinger. Berlin: Mouton de Gruyter, pp. 263-94. [CrossRef]

Braunmüller, Kurt, Steffen Höder, and Karoline Kühl. 2014. Stability and Divergence in Language Contact: Factors and Mechanisms. Amstredam and Philadelphia: John Benjamins Publishing. [CrossRef]

Butcher, Andrew R. 2006. Australian Aboriginal languages: Consonant-salient phonologies and the 'place-of-articulation imperative'. In Speech Production: Models, Phonetic Processes and Techniques. Edited by Jonathan Harrington, and Marija Tabain. New York: Psychology Press, pp. 187-210. [CrossRef]

Carroll, Peter. 1976. Kunwinjku (Gunwinggu): A language of Western Arnhem Land. Master's thesis, The Australian National University, Canberra, Australia.

Corbett, Greville G. 2004. Number. Cambridge: Cambridge University Press. [CrossRef]

Cysouw, Michael. 2003. The Paradigmatic Structure of Person Marking. Oxford: Oxford University Press.

Dickson, Gregory F. 2015. Marra and Kriol: The Loss and Maintenance of Knowledge across a Language Shift Boundary. Ph.D. thesis, The Australian National University, Canberra, Australia.

Dickson, Gregory F. 2016. Rethinking the substrates of Roper River Kriol: The case of Marra. In Loss and Renewal: Australian Languages Since Colonisation. Edited by Felicity Meakins and Carmel O'Shannessy. Boston and Berlin: Walter de Gruyter, vol. 13, pp. 145-74. [CrossRef]

Dixon, R. M. W. 1980. The Languages of Australia. New York: Cambridge University Press. [CrossRef]

Dixon, R. M. W. 2002. Australian Languages: Their Nature and Development. Cambridge: Cambridge University Press. [CrossRef]

Donaldson, Tamsin. 1985. From speaking ngiyampaa to speaking english. Aboriginal History 9: 126-47. [CrossRef] 
Donohue, Mark, Rebecca Hetherington, James McElvenny, and Virginia Dawson. 2013. World Phonotactics Database. Available online: http:/ / phonotactics.anu.edu.au (accessed on 1 July 2018).

Evans, Nicholas. 1992. Macassan loanwords in Top end language. Australian journal of linguistics 12: 45-91. [CrossRef]

Evans, Nicholas. 2003. A Pan-Dialectal Grammar of Bininj Gun-Wok (Arnhem Land): Mayali, Kunwinjku and Kune. Canberra: Pacific Linguistics. [CrossRef]

Evans, Nicholas. 2019. Linguistic divergence under contact. In Historical Linguistics 2015. Paper presented at the 22nd International Conference on Historical Linguistics, Naples, Italy, July 27-31; Edited by Michela Cennamo and Claudia Fabrizio. Amsterdam: John Benjamins, pp. 564-91. [CrossRef]

Evans, Nicholas, Dunstan Brown, and Greville G Corbett. 2001. Dalabon pronominal prefixes and the typology of syncretism: A Network Morphology analysis. In Yearbook of Morphology 2000. Amsterdam: Springer, pp. 187-231.

Fletcher, Janet, and Andrew Butcher. 2014. Sound patterns of Australian languages. In The Languages and Linguistics of Australia. Edited by Harold Koch and Rachel Nordlinger. Berlin: Mouton de Gruyter, pp. 91-138. [CrossRef]

Garde, Murray. 2013. Culture, Interaction and Person Reference in an Australian Language: An Ethnography of Bininj Gunwok Communication. Amsterdam/Philadelphia: John Benjamins Publishing.

Hale, Kenneth. 1959. Gunwinggu Language Elictiation. Unpublished fieldnotes MS878. Canberra: AIATSIS.

Hale, Kenneth. 1964. Classification of Northen Paman languages, Cape York Peninsula, Australia: A research report. Oceanic Linguistics 3: 248-65. [CrossRef]

Harvey, Mark. 2003. Reconstruction of Pronominals among the non-Pama-Nyungan languages. In The Non-Pama-Nyungan Languages of Northern Australia: Comparative Studies of the Continent'S Most Linguistically Complex Region. Edited by Nicholas Evans. Canberra: Pacific Linguistics, pp. 475-513.

Haspelmath, Martin. 2009. Lexical borrowings: Concepts and issues. In Loanwords in the world's Languages: A Comparative Handbook. Edited by Martin Haspelmath and Uri Tadmor. Berlin: de Gruyter Mouton. [CrossRef]

Heath, Jeffrey. 1991. Pragmatic disguise in pronominal-affix paradigms. In Paradigms: The Economy of Inflection. Edited by Frans Plank. Berlin/New York: de Gruyter, pp. 75-89.

Hercus, Luise. 1979. In the Margins of an Arabana-Wanganuru Dictionary: The Loss of Initial Consonants. In Australian Linguistic Studies. Edited by Stephen Wurm. Canberra: Research School of Pacific Studies, The Australian National University, pp. 621-52.

Kapitonov, Ivan. 2019. A Grammar of Kunbarlang. Ph.D. thesis, University of Melbourne, Canberra, Australia.

Labov, William. 1965. On the mechanism of linguistic change. In Report of the Sixteenth Annual Round Table Meeting on Linguistics and Language Studies. Edited by Charles W. Kreidler. Washington: Georgetown University Press, pp. 91-114.

Langlois, Annie. 2004. Alive and Kicking: Areyonga Teenage Pitjantjatjara. Canberra: Pacific linguistics.

Lee, Jennifer R. 1987. Tiwi today: A Study of Language Change in a Contact Situation. Canberra: Pacific Linguistics.

Mansfield, John. 2014. Polysynthetic Sociolinguistics: The Language and Culture of Murrinh Patha Youth. Ph.D. thesis, The Australian National University, Canberra, Australia.

Mansfield, John. 2015. Consonant lenition as a sociophonetic variable in Murrinh Patha (Australia). Language Variation and Change 27: 203-25. [CrossRef]

Mansfield, John. 2016. Borrowed verbs and the expansion of light verb phrases in Murrinhpatha. In Loss and Renewal: Australian Languages Since Colonisation. Edited by Felicity Meakins and Carmel O'Shannessy. Boston and Berlin: Walter de Gruyter, vol. 13, pp. 397-424. [CrossRef]

Marley, Alexandra. 2020. Kundangkudjikaberrk: Language variation and change in Bininj Kunwok, a Gunwinyguan language of Northern Australia. Ph.D. thesis, The Australian National University, Canberra, Australia.

Marley, Alexandra. forthcoming. Sound change in Aboriginal Australia: Word-initial engma deletion in Kunwok. Linguistics Vanguard.

McConvell, Patrick, and Felicity Meakins. 2005. Gurindji Kriol: A mixed language emerges from code-switching. Australian Journal of Linguistics 25: 9-30. [CrossRef]

McGregor, William B. 2013. Verb Classification in Australian Languages. Berlin and New York: Walter de Gruyter. [CrossRef]

McKay, Graham Richard. 1975. Rembarrnga: A Language of Central Arnhem Land. Ph.D. thesis, The Australian National University, Canberra, Australia.

Meakins, Felicity. 2012. Which Mix?-Code-switching or a mixed language-Gurindji Kriol. Journal of Pidgin and Creole languages 27: 105-140. [CrossRef]

Meakins, Felicity, Xia Hua, Cassandra Algy, and Lindell Bromham. 2019. Birth of a contact language did not favor simplification. Language 95: 294-332. [CrossRef]

Meakins, Felicity, and Carmel O'Shannessy. 2012. Typological constraints on verb integration in two Australian mixed languages. Journal of Language Contact 5: 216-46. [CrossRef]

Meakins, Felicity, and Carmel O'Shannessy. 2016. Loss and Renewal: Australian Languages Since Contact. Boston and Berlin: Walter de Gruyter. [CrossRef]

Miestamo, Matti, Kaius Sinnemäki, and Fred Karlsson. 2008. Language Complexity: Typology, Contact, Change. Amsterdam and Philadelphia: John Benjamins Publishing. [CrossRef]

Oates, Lynette Frances. 1964. A Tentative Description of the Gunwinggu Language (of Western Arnhem Land). Master's thesis, University of Sydney, Sydney, Australia. 
O'Shannessy, Carmel. 2004. The Monster Stories: Picture Stimuli for Elicited Production. Unpublished series. Nijmegen: Max Planck Institute for Psycholinguistics.

O'Shannessy, Carmel. 2005. Light Warlpiri: A new language. Australian Journal of Linguistics 25: 31-57. [CrossRef]

Ponsonnet, Maïa. 2019. Difference and Repetition in Language Shift to a Creole: The Expression of Emotions. London: Routledge. [CrossRef]

Poplack, Shana. 2018. Borrowing: Loanwords in the Speech Community and in the Grammar. Oxford: Oxford University Press.

Poplack, Shana, and Stephen Levey. 2010. Contact-induced grammatical change: A cautionary tale. In Language and Space: An International Handbook of Linguistic Variation. Edited by Peter Auer, and Jürgen Erich Schmidt. Berlin: De Gruyter Mouton, pp. 391-419. [CrossRef]

Reid, Nicholas. 2003. Phrasal verb to synthetic verb: Structural change in Ngan'giwutimirri. In The Non-Pama-Nyungan Languages of Northern Australia: Comparative Studies of the Continent'S Most Linguistically Complex Region. Edited by Nicholas Evans. Canberra: Pacific Linguistics, pp. 95-123.

Sandefur, John R. 1986. Kriol of North Australia: A Language Coming of Age. Darwin: Summer Institute of Linguistics, Australian Aborigines Branch.

Saulwick, Adam. 2003. Aspects of the Verb in Rembarrnga: A Polysynthetic Language of Northern Australia: Grammatical Description, Texts and Dictionary. Ph.D. thesis, University of Melbourne, Melbourne, Australia.

Schmidt, Annette. 1983. Young People's Dyirbal: An Example of Language Death from Australia. Master's thesis, The Australian National University, Canberra, Australia.

Schultze-Berndt, Eva. 2003. Preverbs as an open word class in Northern Australian languages: synchronic and diachronic correlates. In Yearbook of Morphology 2003. Edited by Geert Booij and Jaap van Marle. Amsterdam: Springer, pp. 145-77.

Schultze-Berndt, Eva Friederike. 2000. Simple and Complex Verbs in Jaminjung: A Study of Event Categorisation in an Australian Language. Ph.D. thesis, Max Planck Institute for Psycholinguistics, Nijmegen, The Netherlands.

Siegel, Jeff. 2001. Koine formation and creole genesis. In Creolization and Contact. Edited by Norval Smith and Tonjes Veenstra. Amsterdam and Philadelphia: John Benjamins, pp. 175-98. [CrossRef]

Simpson, Jane. 2016. Working verbs: The spread of a loan word in Australian language. In Language, Land and Song: Studies in Honour of Luise Hercus. Edited by Peter K. Austin, Harold Koch and Jane Simpson. London: EL Publishing, pp. 244-62.

Singer, Ruth, and Salome Harris. 2016. What practices and ideologies support small-scale multilingualism? A case study of Warruwi Community, northern Australia. International Journal of the Sociology of Language 2016: 163-208. [CrossRef]

Torres Cacoullos, Rena, and Catherine E. Travis. 2015. Gauging Convergence on the Ground: Code-Switching in the Community. London: SAGE Publications.

Torres Cacoullos, Rena, and Catherine E Travis. 2018. Bilingualism in the Community: Code-Switching and Grammars in Contact. New York: Cambridge University Press.

Trudgill, Peter. 2009. Sociolinguistic typology and complexification. In Language Complexity as an Evolving Variable. Edited by Geoffrey Sampson, David Gil, and Peter Trudgill. Oxford: Oxford University Press, pp. 98-109.

Trudgill, Peter. 2011. Sociolinguistic Typology: Social Determinants of Linguistic Complexity. Oxford: Oxford University Press.

Wohlgemuth, Jan. 2009. A Typology of Verbal Borrowings. Berlin and New York: Mouton de Gruyter. [CrossRef] 